\title{
Very-High-Temperature Gas Reactor Environmental Impacts Assessment
}

\author{
C. D. Baumann \\ C. J. Barton \\ E. L. Compere \\ T. H. Row
}

\section{OAK RIDGE NATIONAL LABORATORY}

UPEKAIEU BY UNION CARBIDE CORPORATION FOR THE ENERGY RESEARCH AND DEVELOPMENT ADMINISTRATION 


\section{DISCLAIMER}

This report was prepared as an account of work sponsored by an agency of the United States Government. Neither the United States Government nor any agency Thereof, nor any of their employees, makes any warranty, express or implied, or assumes any legal liability or responsibility for the accuracy, completeness, or usefulness of any information, apparatus, product, or process disclosed, or represents that its use would not infringe privately owned rights. Reference herein to any specific commercial product, process, or service by trade name, trademark, manufacturer, or otherwise does not necessarily constitute or imply its endorsement, recommendation, or favoring by the United States Government or any agency thereof. The views and opinions of authors expressed herein do not necessarily state or reflect those of the United States Government or any agency thereof. 


\section{DISCLAIMER}

Portions of this document may be illegible in electronic image products. Images are produced from the best available original document. 


\section{Printed in the United States of America. Available from National Technical Information Service \\ U.S. Department of Commerce \\ 5285 Port Royal Road, Springfield, Virginia 22161 \\ Price: Printed Copy $\$ 5.00$; Microfiche $\$ 3.00$}

This report was prepared as an account of work sponsored by the United States Government. Neither the United States nor the Energy Research and Development Administration/United States Nuclear Regulatory Commission, nor any of their employees, nor any of their contractors, subcontractors, or their employees, makes any warranty, express or implied, or assumes any legal liability or responsibility for the accuracy, completeness or usefulness of any information, apparatus, product or process disclosed, or represents that its use would not infringe privately owned rights. 
Contract No. W-7405-eng-26

VERY-HIGH-TEMPERATURE GAS REACTOR ENVIRONMENTAL IMPACTS ASSESSMENT

C. D. Baumann

C. J. Barton*

E. L. Compere**

T. H. Row

Energy Division

Oak Ridge National Laboratory

Oak Ridge, Tennessee 37830

Research sponsored by the Energy Research and Development Administration under contract with the Union Carbide Corporation.

Date Published - August 1977

*Environmental Sciences Divisiun, ret1red

**Chemical Technology Division

Prepared by

OAK RIDGE NATIONAL LABORATORY

Oak Ridge, Tennessee 37830 operated by

UNION CARBIDE CORPORATION

for the

ENERGY RESEARCH AND DEVELOPMENT ADMINISTRATION

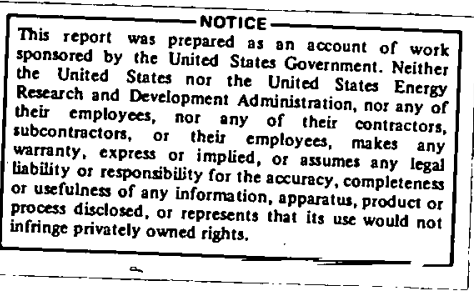

This report was prepared as an account of work
sponsored by the United States Government. the United States nor their employees, nor any of thion, not any of warranty, expres its use would not 
THIS PAGE

\section{WAS INTENTIONALLY \\ LEFT BLANK}




\section{CONTENTS}

$\underline{\text { Page }}$

ABSTRACT . . . . . . . . . . . . . . . . . . . v v

I. Introduction . . . . . . . . . . . . . . . 1

II. Hydrogasification of Coal Liquids Using a VHTR to Supply Steam-Methane Heat and Power . . . . . . . . . 4

III. Description of General Atomic Co. Type VHTR . . . . . . 16

IV. Fission Product Activity and Concentration in the Primary Coolant . . . . . . . . . . . . . . . . 25

V. Noble Gas and Iodine Fission Product Release to the Environment ................. 43

VI. Tritium Release to the Environment . . . . . . . . 53

VII. Safety Considerations . . . . . . . . . . . 64

VIII. Is the Intermediate Heat Exchanger (IHX) Necessary? . . 70 APPENDIX A - Transport of Tritium from VHTR Coolant into SteamMethane Reformer Product Hydrogen . . . . . . . . . . . . 73 


\section{THIS PAGE}

\section{WAS INTENTIONALLY \\ LEFT BLANK}


ABSTRACT

The operation of a Very High Temperature Reactor (VHTR), a slightly modified General Atomic type High Temperature Gas-Cooled Reactor (HTGR) with $1600 \mathrm{~F}$ primary coolant, as a source of process heat for the $1400 \mathrm{~F}$ steam-methanation reformer step in a hydrogen producing plant (via hydrogasification of coal liquids) was examined. It was found that:

(a) from the viewpoint of product contamination by fission and activation products, an Intermediate Heat Exchanger (IHX) is probably not necessary; and

(b) long term steam corrosion of the core support posts may require increasing their diameter (a relatively minor design adjustment). However, the hydrogen contaminant in the primary coolant which permeates the reformer may reduce steam corrosion but may produce other problems which have not as yet been resolved. An IHX in parallel with both the reformer and steam generator would solve these problems, but probably at greater cost than that of increasing the size of the core support posts. It is recommended that this corrosion problem be examined in more detail, especially by investigating the performance of current fossil fuel heated reformers in industry.

Detailed safety analysis of the VHTR would be required to establish definitely whether the IHX can be eliminated. Water and hydrogen ingress into the reactor system are potential problems which can be alleviated by an IHX. These problems will require analysis, research and development within the program required for development of the VHTR. 


\section{VERY-HIGH-TEMPERATURE GAS-COOLED REACTOR}

ENVIRONMENTAL IMPACT ASSESSMENT

\section{INTRODUCTION}

Industrial use of fossil fuels is the largest single energy consumer in the United States, accounting for about $40 \%$ of the total primary energy consumption. Natural gas (51\%), petroleum products (27\%), and coal (22\%) are primary fuels currently used by industry; ${ }^{1}$ the cost of natural gas and petroleum products is increasing rapidly and the long-term supply of these fuels is highly questionable. The use of coal or nuclear fuel in industry would release gas and oil for other uses and would improve the attainment of the nation's goal of national self-sufficiency in energy. Currently, nuclear power plants are beginning to supplant oil and gas fired plants for baseload electrical generation in some parts of the country and, consequently, the applicability of nuclear reactors as sources of process heat is now being seriously investigated in this and other countries. $1,2,3,4$

Many processes such as oil refining, light hydrocarbon reforming, thermochemical dissociation of water, coal conversion, and hydrogen and synthesis gas production, require heat in the 550 to $1100 \mathrm{C}$ (1020 to $2010 \mathrm{~F}$ ) temperature range. This range is above the operating temperature of current Light-Water Reactors (LWRs), but is largely within that of HTGRs [e.g., AVR (Pebble Bed Reactor) in Germany, Dragon in England, and Ft. St. Vrain in the United States]. In fact, the AVR has operated with a primary coolant outlet temperature as high as $950 \mathrm{C}(1740 \mathrm{~F}) .^{5}$ The very nature of HTGRs (i.e., that the fuel and core contain only ceramic materials and the primary coolant is an inert gas, usually helium) permits them to operate at appreciably higher temperatures than LWRs. 
There are many items to be considered in adapting VHTRS to supply process heat. Two factors that are of main concern in this study are:

(1) the possibility that fission and activation products released to the primary coolant may penetrate the heat-exchanger wall and contaminate products made by use of reactor heat or otherwise affect the environment;

(2) the possibility that the product or steam may enter the primary coolant and react with the fuel, core, etc., to the detriment of the reactor.

The introduction of an Intermediate Heat Exchanger (IHX) and its associated loop will help to mitigate problems but this results in an estimated increase in process heat cost of $20 \%$ and in increases in reactor and coolant temperatures of approximately 50-100 C for a given process temperature. Other possible solutions (which will not be consldered further here) are the development of:

(1) negligible pressure drop heat exchangers (e.g., reformers and steam generators) in order to reduce the driving force behind leaks; or

(2) duplex tube heat exchangers. 7

This study involves the calculation of fission and activation product releases to the primary coolant of VHTRs and the assessment of their environmental impact, including their impact through contaminated products in the presence or absence of an IHX. The specific reactor selected for this study is a $3000 \mathrm{MWt}$ General Atomic reactor with somewhat modified prismatic fuel blocks so that primary coolant temperature of $1600 \mathrm{~F}$ (871 C) can be attained with normal H'IGK tuel. ${ }^{8}$ l'he spectelc applicallun of VHTR heat is in the hydrogasification of coal liquids with the VHTR supplying the steam-methane reformer heat at $1400 . \mathrm{F}$ (760 C) as described in Reference 9. The details of the hydrogasification of cosl liquids and a description of the reactor will be discussed in succeeding chapters. 


\section{References}

1. I. Spiewak, J. E. Jones, Jr., G. Samuels, et al., Evaluation of Very High-Temperature Reactors for Process Heat Applications, ORNL-TM-5067 (In Press).

2. I. 'Spiewak, J. E. Jones, Jr., W. R. Gambil, Assessment of Very High Temperature Reactors in Process Applications, ORNL-TM-5242 (Draft).

3. J. J. Williams, et al., Engineering Evaluation of Process Heat Application for Very High Temperature Nuclear Reactors, UE and C - ERDA-750630, United Engineers and Constructors, Inc., June 30, 1975.

4. Proceedings of the First National Topical Meeting on Nuclear Process Heat Applications, Los Alamos Scientific Laboratory, October 1-3, 1974, LA-5795-C (CONF-741032).

5. Page 210, Reference 4.

6. Page 40, Reference 2 .

7. 0. G. Woike, et a1., Small Nuclear Process Heat Plants (SNPH), GEEST 75-001, Genera1 Electric Co., September 1975, page 1-3.

8. D. D. Peterman, R. W. Fontaine, R. N. Quade, L. J. Halvers, and A. M. Jahnomi, Studies of the Use of High-Temperature Nuclear Heat from an HTGR for Hydrogen Production, GA-A13391, General Atomic Co., September 30, 1975.

9. High-Temperature Nuclear Heat Source Study, GA-A13158, Genera1 Atomic Co., September $27,1974$. 
II. HYDROGASIFICATION OF COAL LIQUIDS USING A VHTR

TO SUPPLY STEAM-METHANE HEAT AND POWER

Hydrogen is one of the basic building blocks of modern industry in the U. S. A. It is used in the manufacture of chemicals, in the reduction of iron ore in steel making, in the hydrogenation of edible fats and oils for making margarine and cooking o1ls, in the processing of crude oils and coal to manufacture synthetic pipe line gas, etc. Over the past 25 years, hydrogen has primarily been produced by steam hydrocarbon reforming of natural gas in fossil fuel fired plants as follows:

$$
\begin{aligned}
& \mathrm{CH}_{4}+\mathrm{H}_{2} \mathrm{O}+3 \mathrm{H}_{2}+\mathrm{CO} . \quad \text { (Steam Reforming) } \\
& \mathrm{CO}+\mathrm{H}_{2} \mathrm{O} \rightarrow \mathrm{CO}_{2}+\mathrm{H}_{2} \cdot \text { (Shift reaction) } \\
& \mathrm{CH}_{4}+2 \mathrm{H}_{2} \mathrm{O} \rightarrow 4 \mathrm{H}_{2}+\mathrm{CO}_{2} \text { (overall reaction) }
\end{aligned}
$$

The steam methane reforming reaction is highly endothermic, requiring $49 \mathrm{kcal} / \mathrm{mole}$ (205 kilojoules/mole); this large amount of energy has typically been supplied by the combustion of fuel gas. The use of nuclear heat would allow the substitution of nuclear fuel for a substantial fraction of the natural gas required. However, the increasing cost and scarcity of natural gas provides incentives for developing alternative methods of producing hydrogen.

When coal is exposed to hydrogen at elevated temperature and pressures (hydrogasification) (800 to $850 \mathrm{C}$, and 10 to 100 atmospheres), the reaction produces methane and other light hydrocarbons.

$$
\mathrm{C}+2 \mathrm{H}_{2} \rightarrow \mathrm{CH}_{4} \text { (Hydrogasification) }
$$

Thus the overall plant reaction is

$$
\text { C. } 2 \mathrm{H}_{2} \mathrm{O}+2 \mathrm{H}_{2}+\mathrm{CO}_{2}
$$


The methane and other light hydrocarbons thus produced can be substituted for the natural gas used in the steam reforming step for producing hydrogen. Thus, by the hydrogasification of coal using nuclear heat as a source of process heat, hydrogen can be produced without using a scarce natural resource, natural gas. The preceeding process can also be controlled for the net production of methane or syngas $\left(\mathrm{H}_{2}+\mathrm{CO}\right)$ as desired.

Studies $^{2}$ have shown that coal can be more efficiently used in the process by dissolving it in "coal liquids" (after prior powdering and drying) before the hydrogasification step. Figure 2-1 is a simplified block diagram of the process. Detailed engineering studies ${ }^{1}$ of the process resulted in the conclusion that the process efficiency increases with increasing steam reforming temperature. Detailed flow diagrams and plant flow sheets were prepared for maximum reforming (process) temperatures of $1200 \mathrm{~F}(649 \mathrm{C}), 1400 \mathrm{~F}(760 \mathrm{C}), 1600 \mathrm{~F}(871 \mathrm{C}), 1800 \mathrm{~F}$ (982 C), and $2000 \mathrm{~F}(1093 \mathrm{C})$ with a $3000 \mathrm{MWt}$ VHTR supplying the process heat and power requirements in each case.

The primary coolant temperature of the reactors supplying process heat are about $200 \mathrm{~F}(111 \mathrm{C})$ above the process temperature, hence the reactor requirements for the 1200 and $1400 \mathrm{~F}(649$ and $760 \mathrm{C}$ ) process temperature cases could be met by the current General Atomic. type reactor (e.g. Fulton) without major development. Reactors supplying process heat at temperatures above $1400 \mathrm{~F}$ would require major development. It was mainly for this reason that the $1400 \mathrm{~F}$ process case (1600 F reactor coolant outlet temperature) was selected as the specific case for study in this report. ${ }^{3}$ Details of the $1400 \mathrm{~F}$ case are shown by the flow diagrams (Figures $2-1$ and $2-3$ ) and plant flow sheets (Tables 2-1 and 2-2). 


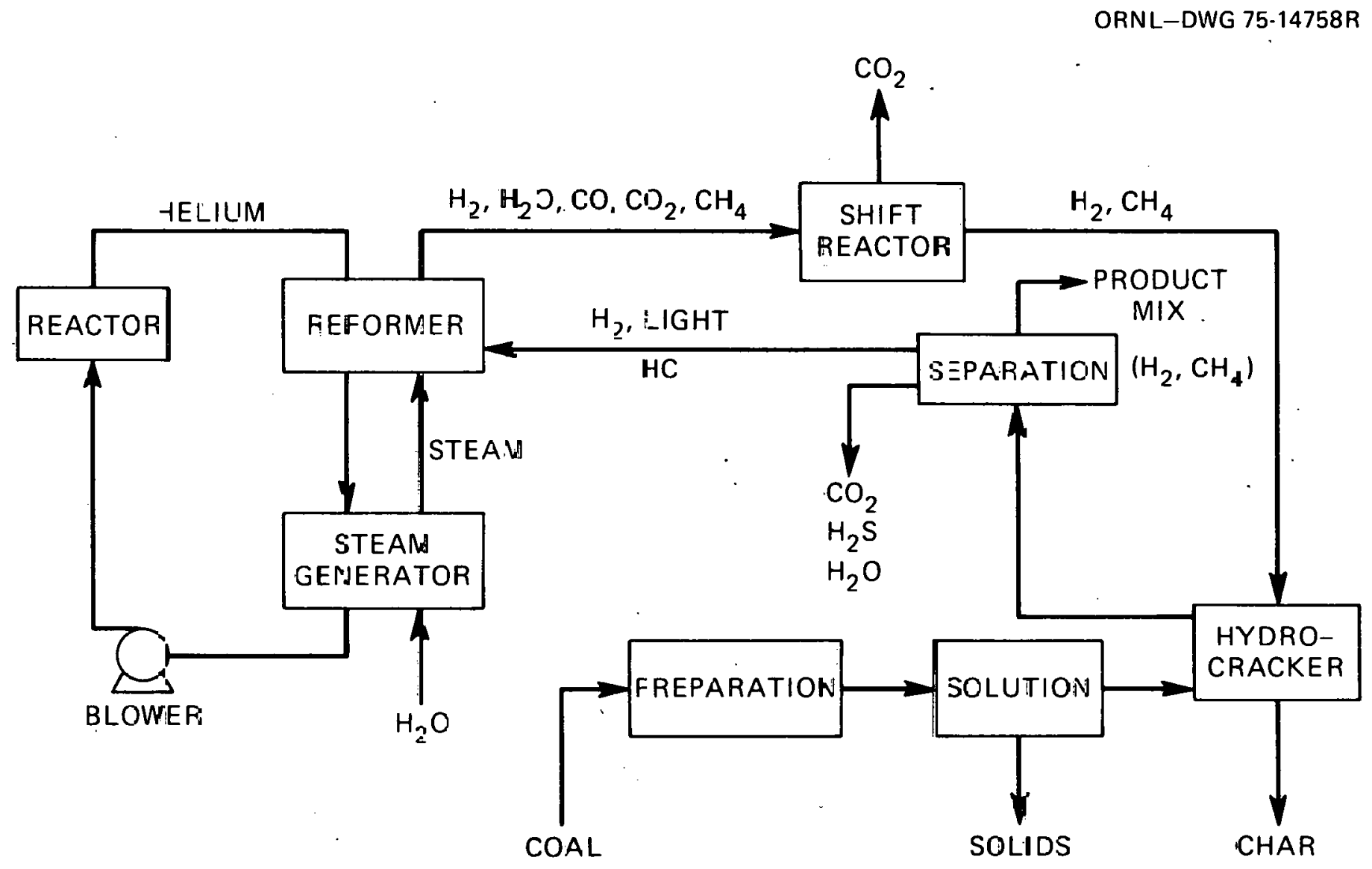

Fig. 2-1. Simflifiec Block Diagram for Solution Hycrocracking of Coal Using a VHTR for Process Heat and Pcwer 
ORNL DWG 77-12884

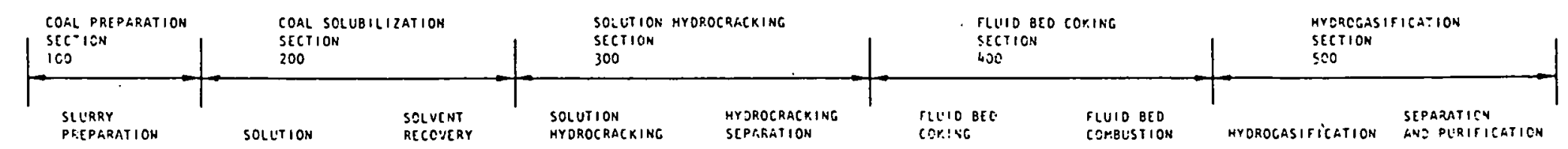

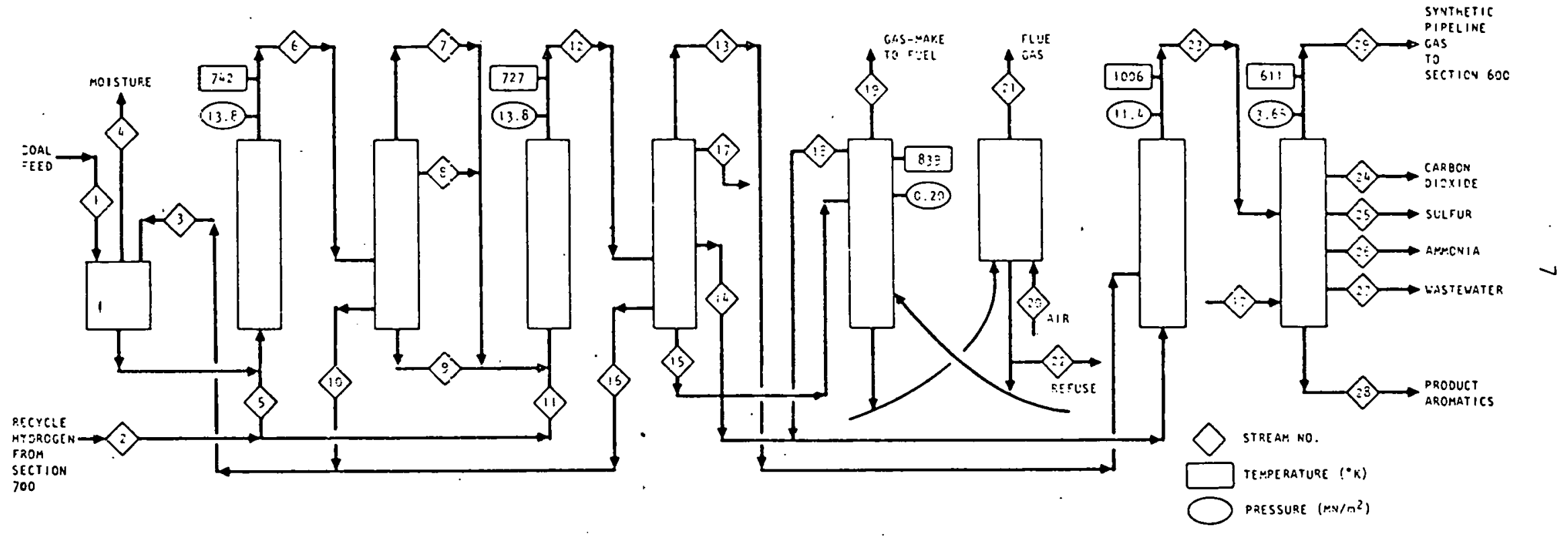

OVERALL STREAM FLOWS SECTIONS 100-500

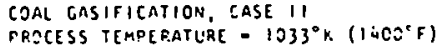

Fig. 2-2. Flow Diagram, Sections 100-500, $\left(1400^{\circ} \mathrm{F}\right)$ 
ORNL DWG 77-12885

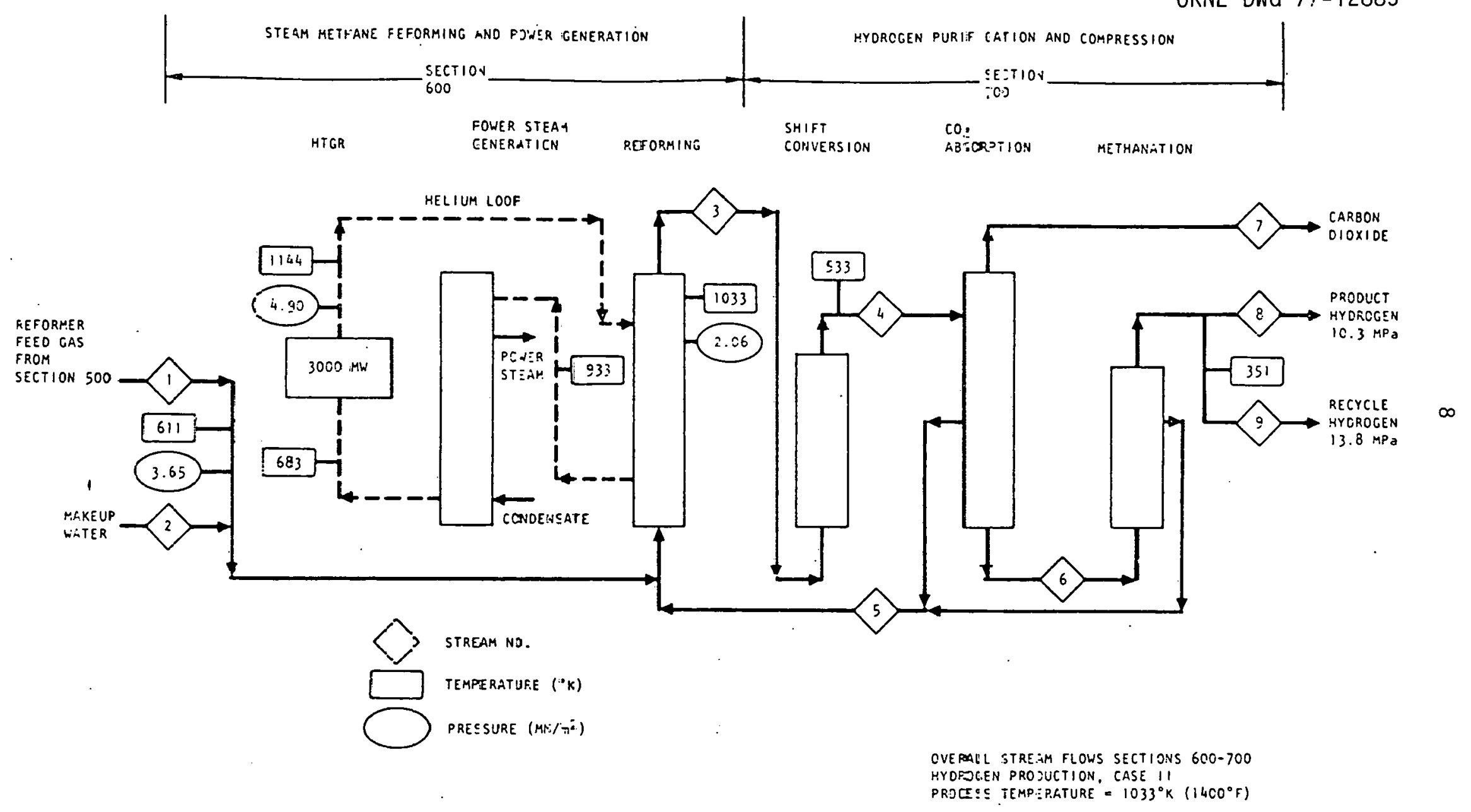

Fig. 2-3. Flow Jiagram, Sections $600-700$, Case $\left(1400^{\circ} \mathrm{F}\right)$ 
ORNL-DWG 77-12886

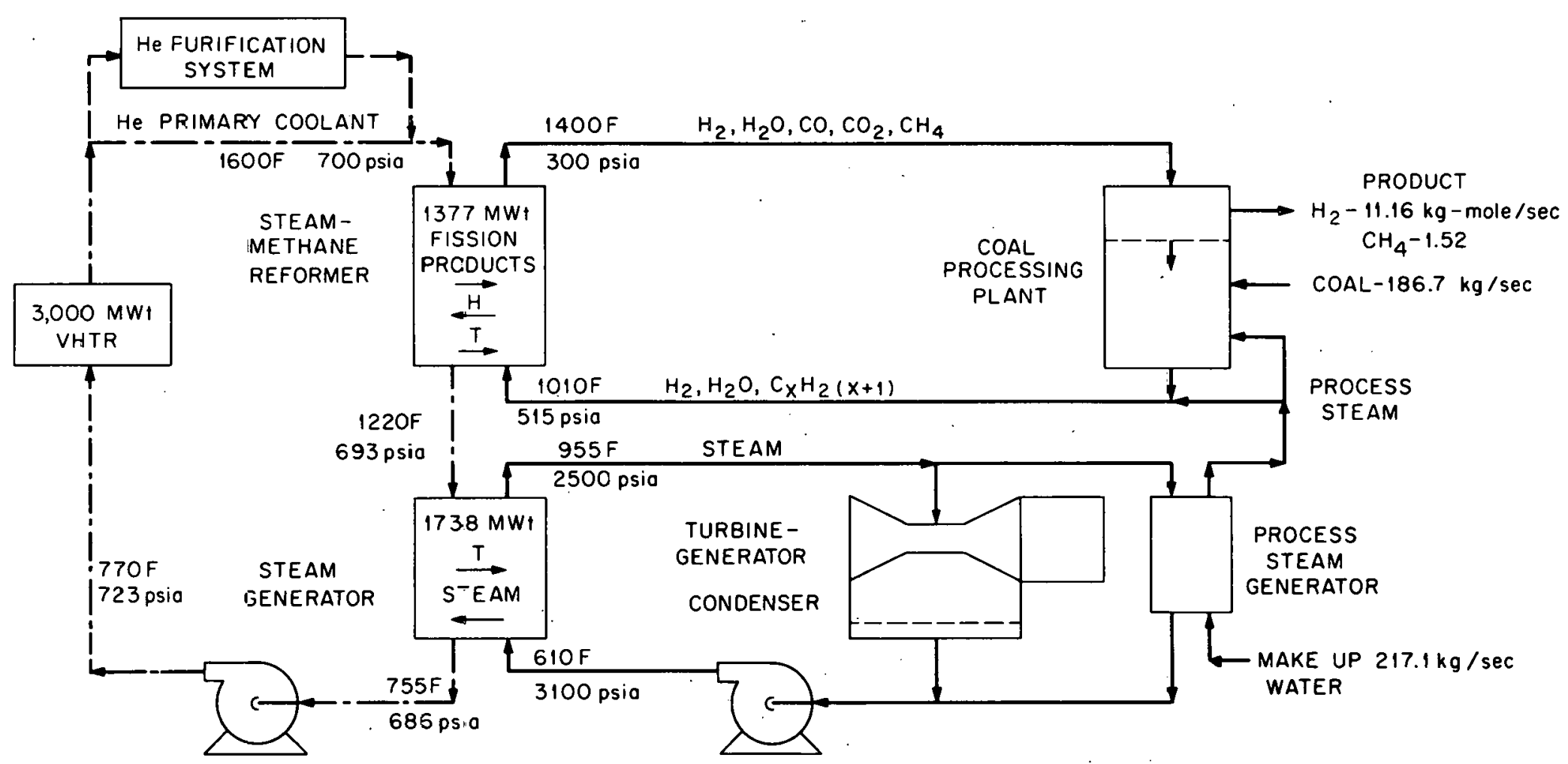

HELIUM CIRCULATOR

Fig. 2-4. Hydrogen Production from Coal Plant with a 3000 MWt VHTR Supplying Process Heat and Power. 
Table 2-1 (Ref. Fig. 2-2)

HYDROGASIFICATION OF COAL EIQUIDS OVERALL PLANT FLONS

PROCESS TEMPERATUR $\Xi=-0 \vdots 3^{\circ} \mathrm{K}\left(1400^{\circ} \mathrm{F}\right)$

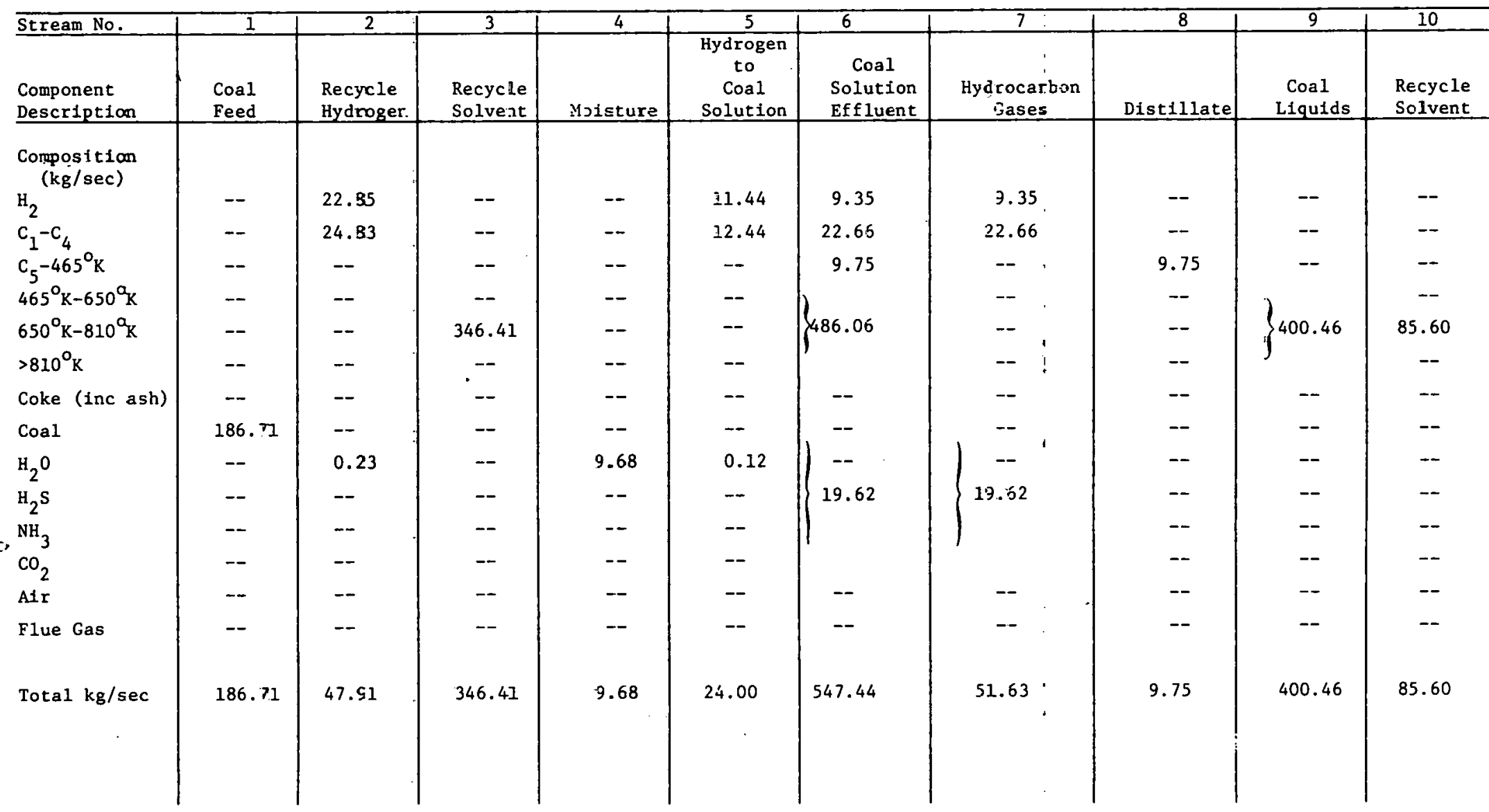

Table Reference GA-Al3391 
Table 2-1 Cont-nued

(Ref. Fig. 2-2;

\begin{tabular}{|c|c|c|c|c|c|c|c|c|c|c|}
\hline Stream No. & 11 & 12 & 13 & 14 & 15 & 16 & 17 & 18 & 19 & 20 \\
\hline $\begin{array}{l}\text { Component } \\
\text { Description }\end{array}$ & $\begin{array}{c}\text { Hydrogen } \\
\text { to } \\
\text { Solution } \\
\text { Hydro- } \\
\text { cracking }\end{array}$ & $\begin{array}{l}\text { Solution } \\
\text { Hydro- } \\
\text { cracker } \\
\text { Effluent }\end{array}$ & $\begin{array}{l}\text { Hydro- } \\
\text { cracking } \\
\text { Product } \\
\text { Gas }\end{array}$ & v & $\begin{array}{l}\text { Heavy } \\
\text { Coal } \\
\text { Liquids }\end{array}$ & $\begin{array}{l}\text { Recycle } \\
\text { Solvent }\end{array}$ & $\begin{array}{l}\text { Acid } \\
\text { Gases }\end{array}$ & $\begin{array}{l}\text { Coal } \\
\text { Liquids }\end{array}$ & $\begin{array}{c}\text { Gas-Make } \\
\text { to } \\
\text { Fuel }\end{array}$ & $\begin{array}{c}\text { Combustion } \\
\text { Air }\end{array}$ \\
\hline $\begin{array}{c}\text { Composition } \\
(\mathrm{kg} / \mathrm{sec})\end{array}$ & & & & & & & & & & \\
\hline $\mathrm{H}_{2}$ & 11.41 & 12.18 & 12.18 & -- & -- & -- & -- & - & 0.68 & - \\
\hline$C_{1}-c_{4}$ & 12.39 & 54.65 & 54.65 & -- & -- & -- & -- & -- & & -- \\
\hline $\mathrm{C}_{5}-465^{\circ} \mathrm{K}$ & -- & $\{77.50$ & -- & $\{77.50$ & -- & -- & -- & -- & -- & - \\
\hline $465^{\circ} \mathrm{K}-650^{\circ} \mathrm{K}$ & -- & & -- & & -- & -- & -- & -- & -- & -- \\
\hline $650^{\circ} \mathrm{K}-810^{\circ} \mathrm{K}$ & - & $\{316.13$ & -- & - & 55.32 & 260.81 & -- & 18.31 & -- & -- \\
\hline$>810^{\circ} \mathrm{K}$ & -- & & - & -- & & -- & -- & -- & -- & -- \\
\hline Coke (inc ash) & -- & -- & . - - & - & -- & -- & -- & -- & -- & -- \\
\hline Coal & -- & -- & -- & -- & -- & -- & - & -- & -- & -- \\
\hline $\mathrm{H}_{2} \mathrm{O}$ & 0.11 & & & -- & -- & -- & & -- & -- & -- \\
\hline $\mathrm{H}_{2} \mathrm{~S}$ & - & 25.29 & 8.06 & -- & -- & -- & 17.23 & -- & -- & -- \\
\hline $\begin{array}{l}\mathrm{NH}_{3} \\
\mathrm{CO}_{2}\end{array}$ & -- & & & -- & -- & -- & & -- & -- & -- \\
\hline Air & - & -- & -- & $\cdot-$ & -- & -- & -- & -- & -- & 19.67 \\
\hline Flue Gas & -- & -- & -- & -- & -- & -- & -- & -- & -- & -- \\
\hline Total kg/sec & 23.91 & 485.75 & 74.89 & 77.50 & 55.32 & 260.81 & -17.23 & 18.31 & 0.68 & 19.67 \\
\hline
\end{tabular}

Table Reference GA-A13391 
Table 2-1 Continued

(Ref. Fig. 2-2)

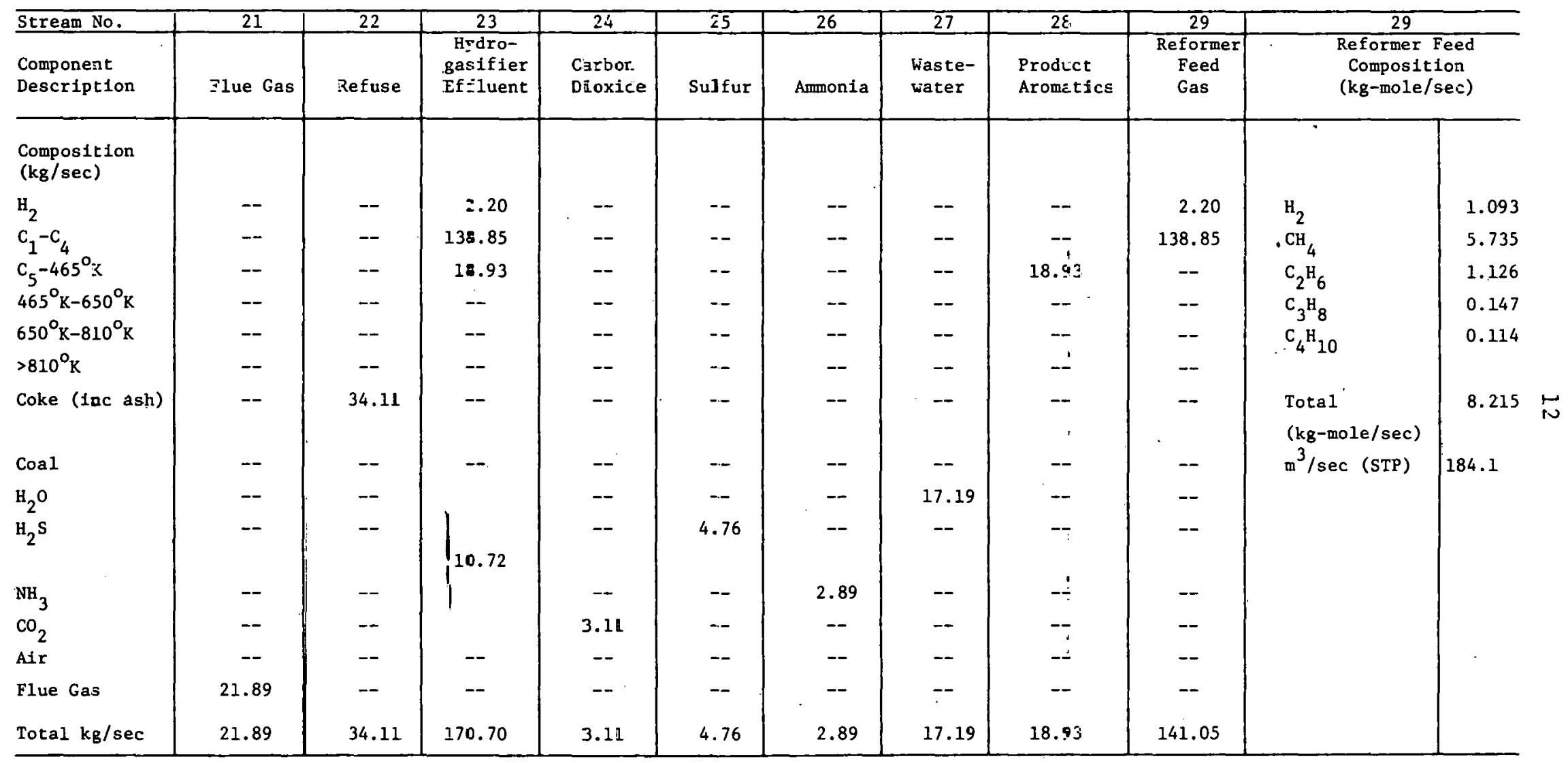

Table Reference GA-Al3391 
TABLE 2-2

HYDROGEN PRODUCTION AND POWER GENERATION OVERALL STREAM FLOWS, FROCESS TEMPERATURE - $1033^{\circ} \mathrm{K}\left(1400^{\circ} \mathrm{F}\right)$ (Ref. Fig. 2-3)

\begin{tabular}{|c|c|c|c|c|c|c|c|c|c|c|c|c|}
\hline Stream No. & 1 & 2 & 3 & 4 & 5 & 6 & 7 & 8 & 9 & Stream No. & 8 & 9 \\
\hline $\begin{array}{l}\text { Component } \\
\text { Description }\end{array}$ & $\begin{array}{l}\text { Reformer } \\
\text { Feed Gas }\end{array}$ & $\begin{array}{r}\text { Makeup } \\
\text { Water } \\
\end{array}$ & $\begin{array}{l}\text { Reformer } \\
\text { Effiuent }\end{array}$ & $\begin{array}{l}\quad \text { Shift } \\
\text { Converter } \\
\text { Effluent } \\
\end{array}$ & $\begin{array}{c}\text { Recycle } \\
\text { Condensate }\end{array}$ & $\begin{array}{l}\text { Carbon } \\
\text { Dioxide } \\
\text { Absorber } \\
\text { Effluent }\end{array}$ & $\begin{array}{l}\text { Carbon } \\
\text { Dioxide }\end{array}$ & $\begin{array}{l}\text { Recycle } \\
\text { Hydrogen } \\
\text { to Coal } \\
\text { Lique- } \\
\text { faction } \\
\end{array}$ & $\begin{array}{r}\text { Product } \\
\text { Hydrogen }\end{array}$ & \begin{tabular}{|} 
Hydrogen \\
$\begin{array}{c}\text { Composition } \\
(\mathrm{kg} / \mathrm{sec})\end{array}$ \\
\end{tabular} & $\begin{array}{l}\text { Recycle } \\
\text { Hydrogen } \\
\end{array}$ & $\begin{array}{l}\text { Product } \\
\text { Hydrogen }\end{array}$ \\
\hline \multicolumn{13}{|l|}{$\begin{array}{l}\text { Composition } \\
(\mathrm{kg}-\mathrm{mole} / \mathrm{sec})\end{array}$} \\
\hline $\mathrm{H}_{2}$ & 1.093 & -- & 21.245 & 23.259 & -- & 23.186 & 0.073 & 11.346 & 11.156 & $\mathrm{H}_{2}$ & 22.85 & 22.47 \\
\hline $\mathrm{SH}_{4}$ & 5.735 & -- & 2.875 & 2.875 & -- & 2.875 & -- & 1.549 & 1.524 & $\mathrm{CH}_{4}$ & 24.83 & 24.42 \\
\hline$z_{2} \mathrm{H}_{6}$ & 1.126 & -- & -- & -- & -- & -- & -- & -- & -- & $\mathrm{Co}$ & -- & -- \\
\hline $\mathrm{C}_{3} \mathrm{H}_{8}$ & 0.147 & -- & - & -- & -- & -- & -- & -- & -- & $\mathrm{CO}_{2}$ & -- & -- \\
\hline $\mathrm{C}_{4} \mathrm{H}_{10}$ & 0.114 & -- & -- & -- & - & -- & -- & -- & -- & $\mathrm{H}_{2} \mathrm{O}$ & 0.23 & 0.22 \\
\hline co & -- & -- & $2.12 i$ & 0.108 & -- & 0.108 & -- & -- & -- & Total kg/sec & 47.91 & 47.11 \\
\hline $\mathrm{CO}_{2}$ & -- & -- & $3.88 i$ & 5.901 & -- & 0.090 & 5.811 & -- & -- & & & \\
\hline $\mathrm{H}_{2} \mathrm{O}$ & -- & 12.064 & $30.18 ?$ & 28.173 & 28.019 & 2.194 & 0.417 & 0.013 & 0.012 & & & \\
\hline $\mathrm{kg}-\mathrm{mole} / \mathrm{sec}$ & 8.215 & 12.064 & 60.316 & 60.316 & 28.019 & 28.453 & 6.301 & 12.908 & 12.692 & & & \\
\hline $\mathrm{kg} / \mathrm{sec}$ & $i 41.05$ & 217.14 & 862.50 & 862.50 & 504.31 & 139.24 & 263.17 & 47.91 & 47.11 & & & \\
\hline
\end{tabular}

Table Reference GA-A13391 
The VHTR which provides the heat for steam methane reforming and power generation is depicted in Section 600 of Fig. 2-3. Figure 2-4 is a redrawing of the plant emphasizing the reactor (and its appurtenances) portion of the system. The reactor is described in the next section of this report. 


\section{References}

1. D. D. Peterman, R. W. Fontaine, R. N. Quade, L. J. Halvers, and A. M. Jahnomi, Studies of the Use of High-Temperature Nuclear Heat from an HTGR for Hydrogen Production, GA-A13391, General Atomic Co., Sept. 30, 1975.

2. General Atomic Company and Stone and Webster, "Application Study of a Nuclear Coal Solution Casification Process for Oklahoma Coal", GA-A12068, May 1972 .

3. Personal Communication, John E. Jones, Jr., Oak Ridge National Laboratory.

\section{Figures}

2-1. Simplified Block Diagram for Solution Hydrocracking of Coal Using a VHTR for Process Heat and Power (ORNL Drwg. 75-14758).

2-2. Hydrogasjification of Coal Liquids Flow Diagrams, Sections 100-500, 1400 F Case (Fig. 5-1 of GA-A13391).

2-3. Hydrogen Production and Power Generation Flow Diagrams, Sections 600700, $1400 \mathrm{~F}$ Case (Fig. 5-2 of GA-A13391).

2-4. Hydrogen Production from Coal Plant with a 3000 MWt VHTR Supplying Process Heat and Power.

\section{List of Tables}

2-1. Hydrogasification of Coal Liquids Overall Plant Flows, Process Temperature $1033 \mathrm{~K}$ (1400 F) (Tab]e $5-5$ of GA-A13391).

2-2, Hydrogen Production and Power Generation Overall Stream Flows, Process Temperature $1033 \mathrm{~K}(1400 \mathrm{~F}$ ) (Table 5-6 of GA-A13391). 
III. DESCRIPTION OF A GENERAL ATOMIC CO. TYPE VHTR

In general, as was stated previously, HTGRs are capable of operating at higher temperatures than most other types of reactors because both the fuel (oxides or carbides of enriched uranium and thorium) and the moderator (graphite) are ceramic materials and the coolant is an inert gas, normally helium. This applies to the General Atomic type HTGR (e.g., Fulton Generating Station) which, with some modifications, serves as the VHTR which supplies both process heat and power for the process under study - the production of hydrogen from coal and water.

The primary source of heat in a HTGR is the fissioning of fisstle material (usually uranj.um enriched in ${ }^{235_{U}}$, or ${ }^{233} \mathrm{U}$ that has been converted from ${ }^{232} \mathrm{Th}$ ) in fuel particles which are micro-spheres less than a millimeter in diameter. The fuel particles are bonded together with a graphite binder to form fuel rods which are then stacked in individual fuel holes of a graphite fuel block (see Figure 3-1). The fuel blocks are hexagonal prisms which contain coolant channels for the flow of the helium primary coolant. Many of these blocks are stacked side by side and above each other to form the core of the reactor. The helium primary coolant passes downward thru the core to a plenum. The heated gas then enters one of several (in this case six) loops which consist of a steam generator and helium circulator in series. In the steam generator some of the heat contained in the helium is used to generate steam which, in turn, may be used to power turbine-generators for the production of electricity. The helium, after passing thru the steam generator, is compressed by the helium circulator and sent to a plenum at the top of the core of the reactor to start the cycle over again. The reactor is completely enclosed by a thick walled Pre-stressed Concrete Reactor Vessel (PCRV) which isolates the reactor and primary 
coolant from the environment, and also provides shielding from the radiation generated by the reactor during the fissioning process (i.e., the radioactive fission products). The steam generators and helium circulators are located in cavities ("pods") within the walls of the PCRV.

The Ceneral. Atomic type VHTR with $1600 \mathrm{~F}(871 \mathrm{C})$ primary coolant is a HTGR (e.g., Fulton Generating Station) modified by:

1) adding a process heat exchanger (in this case a reformer) in series with and upstream of the steam generator;

2) deleting the reheat section of the steam generator, i.e., the steam generator consists of an economizer, evaporator and superheater only, and

3) utilizing a somewhat different fuel block. The fuel holes and coolant holes are increased in number and decreased in diameter so that the coolant temperature can be increased without increasing the fuel temperature.

Figure 3-2 is a drawing of a typjcal GA type VHTR with the reformer located in the PCRV. ${ }^{2}$ The helium coolant flows downward thru the core where it is heated to about $200 \mathrm{~F}$ (111 C) above the required process temperature. It then passes thru one of six loops, upward thru a reformer, downward thru an adjacent steam generator, upward around the same steam generator and finally thru a helium circulator where it is compressed and sent back to the plenum above the core.

In this case, the modifications to the fuel. block permit normal HTGR fuel particles to be used in the VHTR because the maximum fuel particle temperature in the VHTR will not exceed that in the HTGR. The fuel particles are of two types, fissile and fertile as shown in Fig 3-3. Fissile particles consist of a kernel of highly enriched UC which is coated with a layer of low density pyrolitic carbon (the buffer layer), a layer of high density pyrolitic carbon, a layer of silicon carbide, and another layer of high density pyrolitic carbon." The fertile particles have a kernel of thoria followed by a buffer 
layer of low density pyrolitic carbon and by a single layer of high density pyrolitic carbon.

Most of the fissions that take place in the core occur in the kernel of the fissile particles. The buffer layer shields the inner, high-density pyrolitic carbon coating from fission product recoils from (or near) the surface of the kernel and also provides a storage space for gaseous fission products which escape from the kernel. The inner pyrolitic carbon coating serves as a container to confine the gaseous fission products within the particle whereas the silicon carbide coating acts as a barrier for volatfle metallic fission products.

The fertile particles are used to convert ${ }^{232}$ Th to fissionable $233_{\mathrm{U}}$

Results of many inpile tests indicate that intact fuel particles are quite successful in retaining most of the fission products within the particle under normal HTGR operating conditions. ${ }^{3}$ However, intact particles do leak a small fraction of the fission products. Also, a small fraction of the particles are imperfect or fail during the course of irradiation and release a larger fraction of fission products than do intact particles. One of the major goals of this investigation is to produce estimates of the release and to predict the fate of fission products, to determine their effect upon the environment, and especially their effect on plant products.

In order to limit the activity level in the primary coolant, a fraction of the coolant flow is directed to the Helium Purification System where the noble gas fission products (krypton and xenon isotopes) and contaminating gases such as hydrogen, tritium, water vapor, etc. are nearly all completely removed from the bypass stream. The fraction of primary flow sent to the purification system (as indicated by the turnover time) is a strong determinant of the steady state activity of the primary coolant. 
The Helium Purification System consists of two identical trains located in the top head of the PCRV. ${ }^{4}$ A train consists of:

a) high temperature filter adsorbers which remove dust particles, metallic and volatile electronegative fission products (e.g. iodine);

b) coolers and dryers which remove water vapor and carbon dioxide;

c) Low temperature $(-187 \mathrm{C},-305 \mathrm{~F})$ absorbers which remove fission product noble gases (both stable and radioactive krypton and xenon isotopes) and impurities such as CO, nitrogen, hydrogen (including tritium) and methane. All these impurities are totally removed in this section except hydrogen and tritium.

The purified helium strean then goes from the PCRV to the hydrogen removal section where titanium sponge getters remove the hydrogen and tritium from the stream.

When a train becomes saturated as indicated by breakthrough of any of the impurities in the stream, the helium flow is switched to the standby train. After some delay time (which allows most of the short lived nuclides to decay) the initial train is regenerated and put in standby condition. Part of the regeneration procedure is the removal of the titanium sponge getter which becomes loaded with hydrogen and tritium and its replacement with fresh sponge. The tritiated sponge is then processed as solid waste.

The reformers used for the process under study are somewhat similar in size and shape to the steam generators (Fig. 3-4) and thus can be installed in the walls of the PCRV. Specific methods have to be developed for the periodic changing of the catalyst used in the reforming step.. 

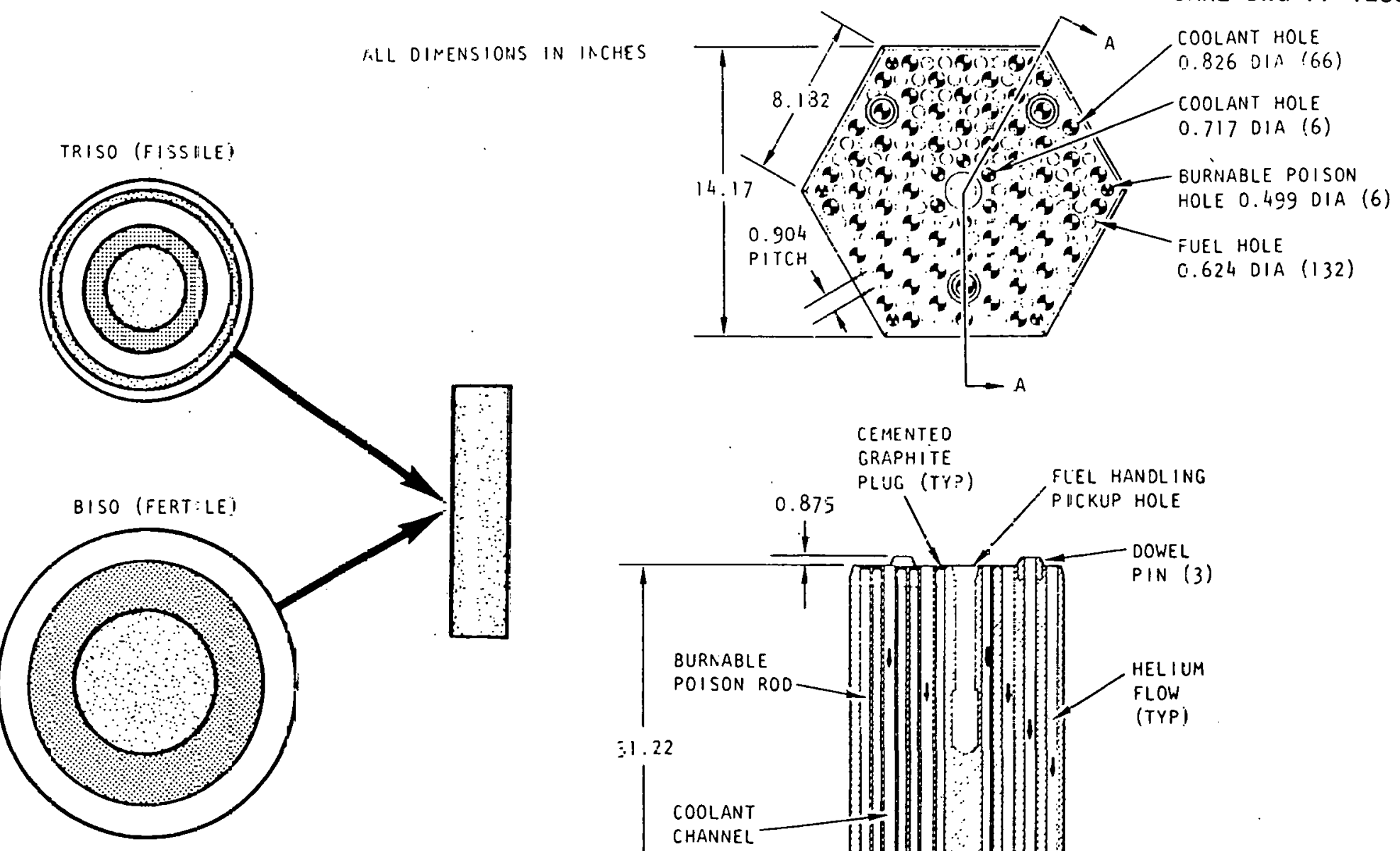

FUEL PARTICLES

RUEL ROD

SCALE: $100 \times$

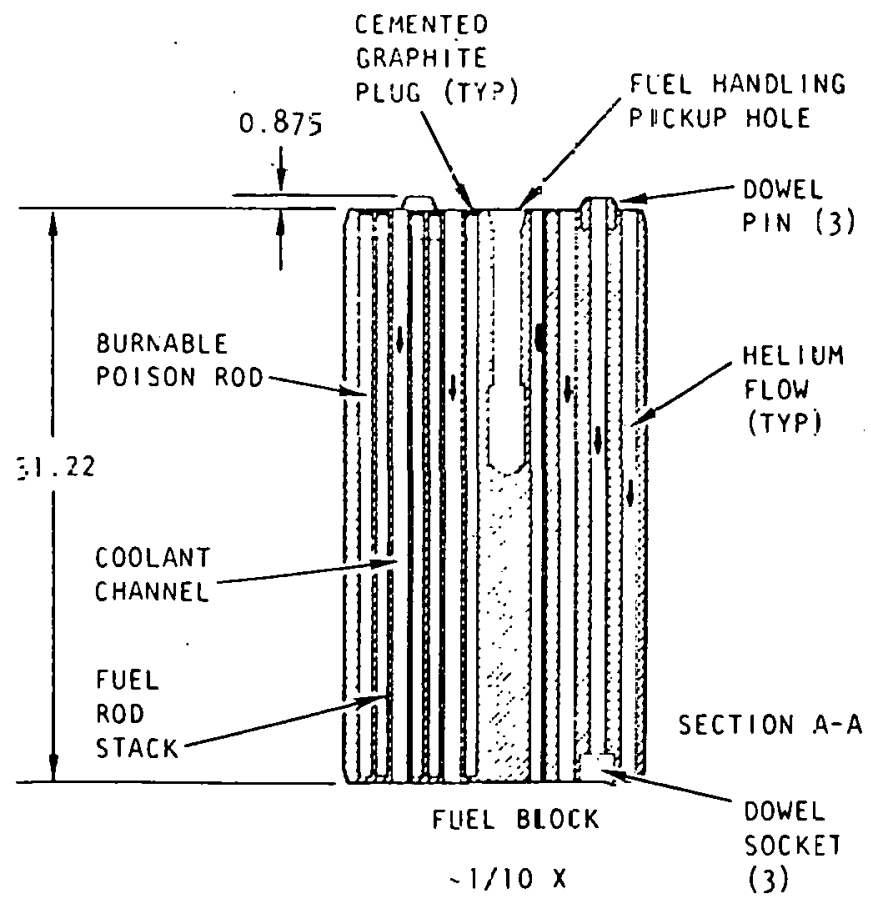

Fig. 3-1. Large HTGR ‡uel element design (all dimensiors ir. inches) 
ORNL DWG 77-12888

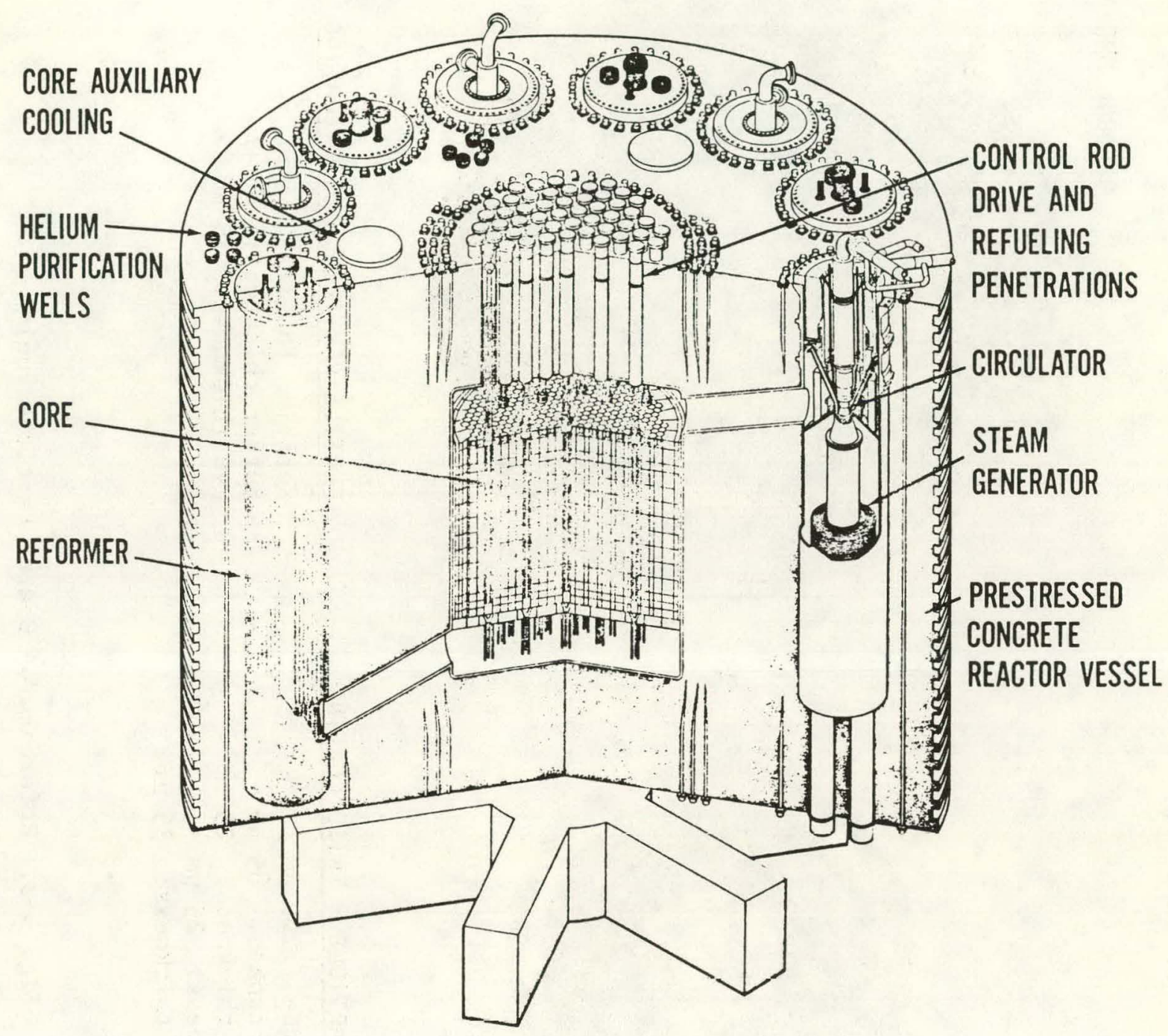

Fig. 3-2. General Atomics VHTR 

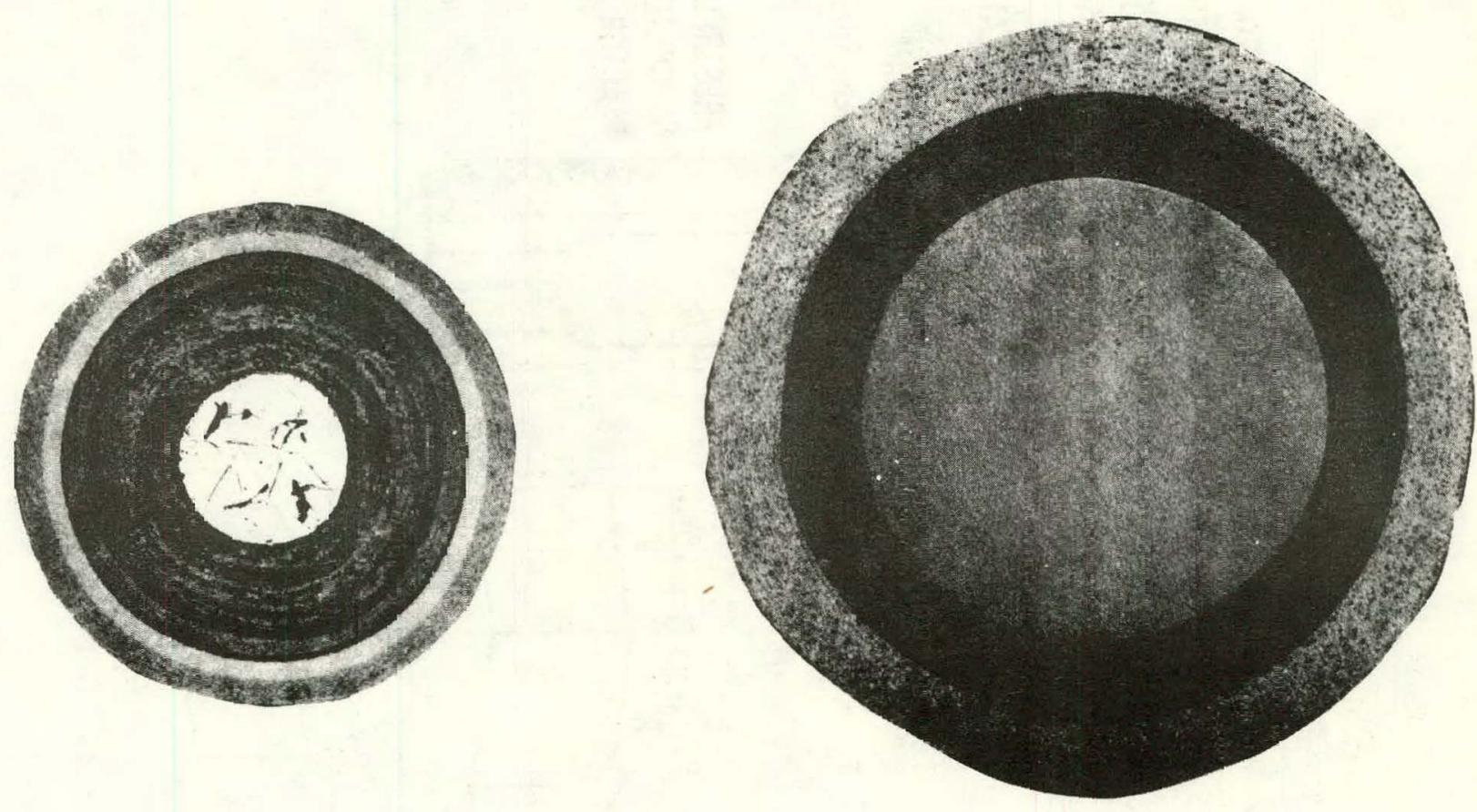

\section{FISSILE P.ART CLE - TRISO COATING}

Kernel $-\mathrm{JC}_{2} \quad 200 \mu \mathrm{m}$ Buffer thickness: $85 \mu \mathrm{m}$ Inner PyC thickness: $25 \mu \mathrm{m}$ SiC thickness: $25 \mu \mathrm{m}$ Guter PyC thickness: $35 \mu \mathrm{m}$

\section{FERTILE PARTICLE - BISO COATING}

Kernel - $\mathrm{ThO}_{2}: 500$ rm Buffer thickiess: 85 , PyC thickness: $75 \mu \mathrm{m}$

$73 \mathrm{~K} 426$

Fig. 3-3. Reference GA Coated Particle Fuels 


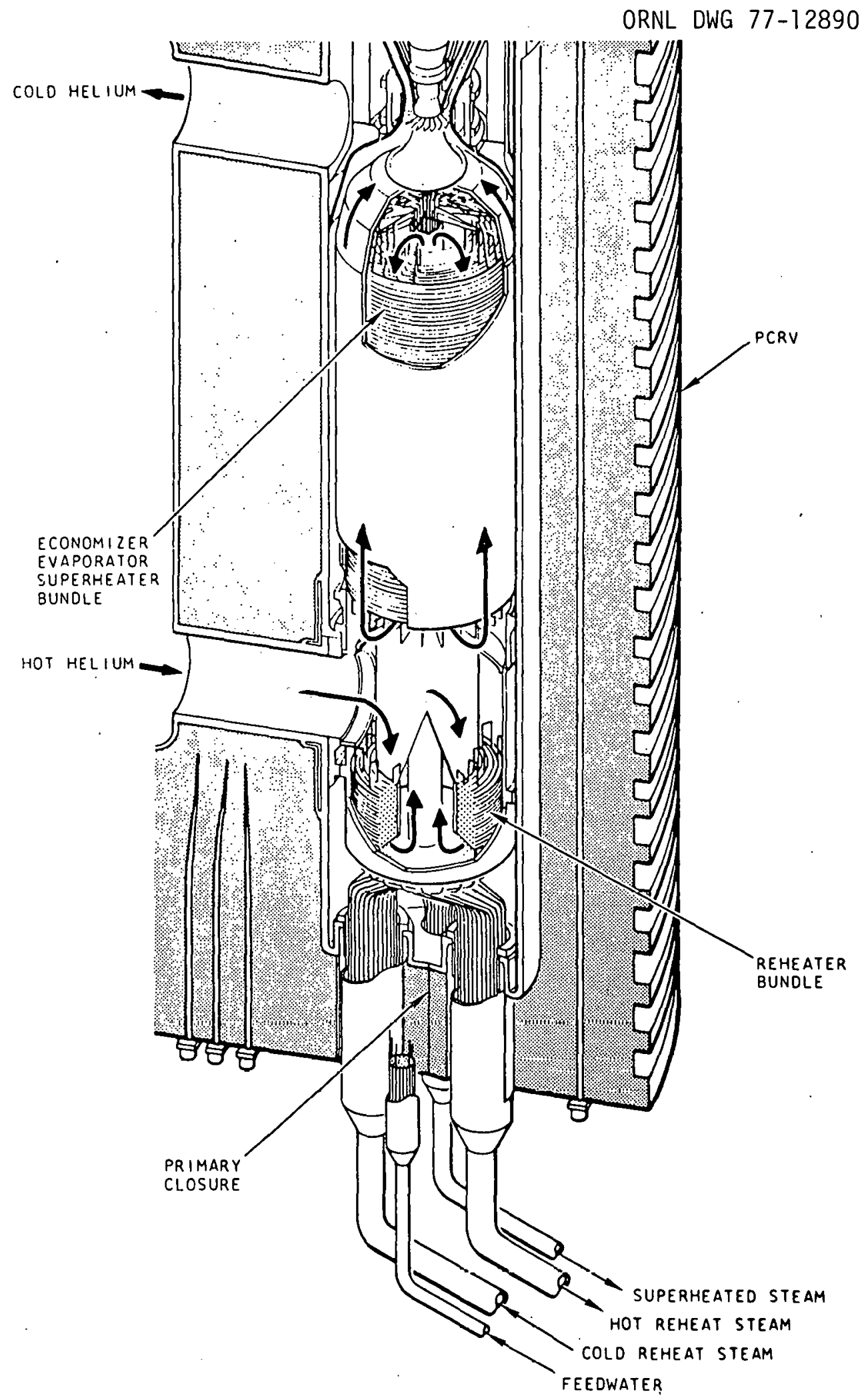

Fig. 3-4. HTGR MK 1 steam generator 


\section{References}

1. A. W. Barse11 and M. B. Peroomian, Consequences of Water Ingress into the HTGR Primary Coolant, GA-A13171, General Atomic Co., Apri1 15, 1975.

2. High-Temperature Nuclear Heat Source Study, GA-Al3158, General Atomic Co., Sept. 27, 1974 .

3. M. J. Haine and D. W. McEachern, Gaseous Radioactivity Levels in the Primary Coolant of an HTGR, General Atomic Co., GA-A12946, Oct. 1, 1974.

4. Fulton Generating Station Preliminary Safety Analysis Report, Section 9.3.1, Philadelphia Electric Co.

\section{Eigures}

3-1. Large HTGR Fuel Element Design (Fig. 2-1 of GA-A13171).

3-2. General Atomic Type VHTR (Fig. 2-1 of GA-A13158).

3-3. Reference GA Coated Particle Fuels (F1g. 2-2 of GA-A12946).

3-4. HTGR MKI Steam Cenerator (Fig. 2-2 of GA-A13171). 
IV. FISSION PRODUCT ACTIVITY AND CONCENTRATION

IN THE PRIMARY COOLANT'

The noble gas fission product activity in the primary coolant was calculated using a modification of a computer program developed by M. J. Bell of the Effluent Treatment Systems Branch, NRC. The program is based in part on the "RAD-2" program as detailed in References 1 and 2.

In calculations of the inventory of radioactive nuctides in the primary systen of an HTGR, the helium coolant is considered to be a wellstirred volume of gas to which fission product nuclides are added continously as they escape from the reactor fuel elements. Fission product nuclides are continuously removed from the mixture of coolant and impurities by radioactive decay, by the purification system, and by plateout on surfaces within the primary coolant circuit. Thus, the total inventory of any fission product in the primary system at any given time is distributed among three "locations":

1. The core, i.e., material that has not yet been released from the fuel and has not been lost by radioactive decay or neutron capture, $\mathrm{N}_{i \text {, core }}$

2. The coolant, i.e., materia]. that has been released from the fuel but has not been plated out or lost by radioactive decay or removal by the purification system, $\mathrm{N}_{i G}$ and

3. System surfaces, i.e., material that has been released from the fuel and plated on surfaces, but has not undergone radioactive. decay, $\mathrm{N}_{\text {ip }}$.

The primary barriers preventing escape of radionuclides from the fuel into the coolant are the fuel particle coatings. The release rate. of gaseous nuclides from fuel particles with intact coatings is much smaller than their rate of birth. The small release which does occur 
results primarily from fuel contamination in the coatings. The fractional release of radioactive gaseous nuclides from fuel particles with failed coatings is several orders of magnitude higher than that from fuel particles with intact coatings, but generally it is still significantly less than 1.0. A fractional release, averaged over the whole core, is obtained from the effective fraction of failed and intact fuel particle coatings and their respective fractional releases at the operating cunditions of the reactor.

As mentioned in the previous chapcer, 1mpurlties dit letuved from the primary coolant helium by a sidestream purification system. ${ }^{3}$ In addition to the helium purification system, the steam generators and other reactor components are effective in removing, by deposition on surfaces, fission products other than noble gases. The plateout rate is a function of the particular species being considered, flow dynamics, circuit surface conditions, temperatures, and operating history. Removal resulting from plateout is very effective in reducing the activity level of condensible species in the circulating gas stream. Thus, noble gases constitute the major fraction of the gaseous radioactivity in the primary coolant. Remuval resulting from radioactive decay is determined on the basis of decay constants given in the 1iterature. The following treatment deals with the absolute inventories, $N_{i}$ (number of atoms), of the fission product nuclides and with their activities, $A_{i}$ (Curies).

The primary coolant inventory for the first member of a decay cliaim, $\mathrm{N}_{1 G}$, is expressed by

$$
\frac{\mathrm{dN}_{1 \mathrm{O}}}{\mathrm{dt}}=(\overline{\mathrm{R} / \mathrm{B}})_{1, \text { core }} \mathrm{B}_{1, \text { core }}-\left(\lambda_{1}+\mathrm{r}_{\mathrm{s}}+\mathrm{r}_{\mathrm{p}}\right) \mathrm{N}_{1 \mathrm{r}}
$$


where

$$
\begin{aligned}
& \mathrm{N}_{1 G}=\text { atoms in the coolant at time } \mathrm{t} \\
& t=t i m e, \text { sec } \\
& (\overline{R / B})_{1} \text {, core }=\text { core-average fractional release of isotope } 1 \text {. } \\
& { }^{\mathrm{B}} 1 \text {, core }=\text { birth rate of isotope } 1 \text { in fuel, number per second } \\
& \lambda_{1}=\text { decay constant of isotope } 1, \sec ^{-1} \\
& r_{s}=\text { removal constant due to purification system, } \sec ^{-1} \\
& r_{p}=\text { removal constant resulting from deposition of conden- } \\
& \text { sible species on surfaces of primary coolant circuit, } \\
& \sec ^{-1} \text { and } \\
& (\overline{R / B})_{i} \text {, core }=f(R / B)_{i} \text {, failed }+(1-f)(R / B)_{i} \text {, intact }
\end{aligned}
$$

where

$$
f=\text { fraction of failed fuel }
$$

The birth rate of the isotope is calculated as

$$
\mathrm{B}_{1, \text { core }}=\left(3.15 \times 10^{10}\right) \mathrm{P} \mathrm{Y}_{1}
$$

where

$$
\dot{P}=\text { thermal power of reactor, watts }
$$

$\mathrm{Y}_{1}=\mathrm{fission}$ yield of isotope 1 , fraction per fission

The constant, $3.15 \times 1.0^{10}$, is the number of fissions per second required to produce one watt of thermal power.

In Eq. I it is assumed that the coolant sidestream purification system samples the well-mixed coolant. The sidestream removal constant, $r_{s}$, is computed from plant operating conditions by

$$
r_{s}=\frac{m_{s}}{M}
$$

where

$$
\begin{aligned}
& m_{s}=\text { sidestream purification system mass flow rate, } 1 \mathrm{~b} / \mathrm{sec} \\
& M=\text { total mass of circulating primary coolant, } 1 \mathrm{~b} .
\end{aligned}
$$


It is assumed that no fission products entering the purification system are returned to the primary coolant. ${ }^{3}$ This is accomplished in the HTGR by monitoring the activity of the coolant returned to the primary system from the purification plant. When activity is detected, the purification plant sidestream is diverted to a fresh trapping system, and the first system is regenerated by purging with clean helium (Ref. 3).

The plateout removal rate constant, $r_{p}$, is described by

$r_{p}=\frac{m_{C}}{M} \ln (1-\tau)$

where

$\tau=$ fraction of condensible nuclide gas phase inventory that plates out during one complete pass around primary coolant circuit, i.e., plateout per pass,

$\mathrm{m}_{\mathrm{C}}=$ primary coolant mass flow rate, $1 \mathrm{~b} / \mathrm{sec}$

$M=$ total mass of circulating primary coolant, $1 \mathrm{~b}$.

The time required to make one complete pass around the primary coolant loop, $\theta$, is estimated as $\theta=\mathrm{M} / \mathrm{m}_{\mathrm{C}}$. If $\tau \ll 1$, Eq. 5 can be approximated as $r_{p} \approx \tau / \theta$. The fractional plateout per pass, $\tau$, is different for each chemical element and its value is listed in the program inpur.

Using the initial condition, $\mathrm{N}_{1 G}(t=0)=0$, and assuming that the release rate, purification, and plateout constants remain unchanged with time, the solution of $\mathrm{Eq}$. 1 for $A_{1 G}$ (the activicy of nucllate 1), expressed in curies is

$$
\Lambda_{1 G}=\frac{0.85(\overline{R / B})_{1}, \text { core }{ }^{R}{ }_{1} \text { core }}{1+\frac{r}{\lambda_{1}}}\left(1-e^{-\left(\lambda_{1}+r\right) t}\right)
$$

where

$$
\begin{aligned}
& r=r_{s}+r_{p} \\
& A_{1 G}=\frac{\lambda_{1} N_{1 G}}{3.7 \times 10^{10}} \text { curies }
\end{aligned}
$$


For subsequent isotopes in the decay chain, the activity becomes

$$
\begin{aligned}
A_{i G}=\{[ & 0.85 P\left(Y_{i}-X_{i-1} Y_{i-1}-X_{i-2} Y_{i-2}\right)+X_{i-1} A_{i-1}, \text { core } \\
& \left.+X_{i-2} A_{i-2,} \text { core }\right](\overline{R / B}) \\
& \left.+X_{i-1} A_{i-1, p}+X_{i-2} A_{i-2, p}\right\}\left\{\left(1-e^{-\left(\lambda_{i}+r\right) t}\right) /\left(1+r / \lambda_{i}\right)\right\}
\end{aligned}
$$

where the value of the yield $\mathrm{Y}$ is the cumulative yield and $\mathrm{X}$ is the branching ratio. Subscripts $i-1$ and $i-2$ denote parents and grandparents of isotope $i$. If an isotope does not decay directly from a parent or grandparent isotope of a decay chain, then the respective branching ratios are zero. $A_{i p}$ is the plateout activity from Eq. 11.

The core activity of the first member in a chain is

$$
\mathrm{A}_{1, \text { core }}=\frac{\lambda_{i} \mathrm{~N}_{1, \text { core }}}{3.7 \times 10^{10}}=0.85 \mathrm{PY}_{1}(1-(\overline{\mathrm{R} / \mathrm{B}}) 1, \text { core })\left(1-\mathrm{e}^{-\lambda_{1} \mathrm{t}}\right)
$$

More generally, the equation used to establish the core activity cf an isotope which is formed directly in the fission process and which decays from parents and grandparents is given by

(Eq. 9)

$$
\begin{aligned}
& A_{i, \text { core }}=\left[0.85 P\left(Y_{i}-X_{i-1} Y_{1-1}-X_{1-2} Y_{i-2}\right)+X_{i-1} A_{i-1}\right. \text {, core } \\
& \left.+x_{i-2} A_{i-2, \text { core }}\right](1-(\overline{R / B}) i, \text { core })\left(1-e^{-\lambda_{1} t}\right)
\end{aligned}
$$

The plateout activity of the first member in a chain is

$$
A_{1 p}=\frac{\lambda_{1} \mathrm{~N}_{1 \mathrm{p}}}{3.7 \times 10^{10}}=0.85(\overline{\mathrm{R} / \mathrm{B}}){ }_{1, \text { core }} \mathrm{PY}_{1}\left(1-\mathrm{e}^{\left.-\cdot \lambda_{1} \mathrm{t}_{\mathrm{p}}\right)}\right.
$$

where t $p$, sec, is the operating time of the plant. 
The equation used to calculate the plateout activity of succeeding radionuclides in the decay chain is

$$
\begin{aligned}
A_{i p}=\{ & {\left[0.85 P\left(Y_{i}-x_{i-1} Y_{i-1}-x_{i-2} Y_{i-2}\right)+X_{i-1} A_{i-1}\right. \text {, core }} \\
& \left.+x_{i 2} A_{i-2,} \text { core }\right]^{(\overline{R / B})}{ }_{i, \text { cole }}+x_{i-1} A_{i-1, p}, \\
& \left.+x_{i-2} A_{i-2, p}\right\}\left(1-e^{-\lambda_{i} t} p\right)
\end{aligned}
$$

The fundamental equation used to calculate the fractional release, $\mathrm{R} / \mathrm{B}$, of a radionuclide from either failed or intact fueled micrn-spheres is the "equivalent sphere" mode1"

$$
(R / B)_{i}=\frac{3}{\sqrt{\lambda_{i} / D^{\prime}}}\left[\operatorname{coth} \sqrt{\lambda_{i} / D^{\prime}}-\frac{1}{\sqrt{\lambda_{i} / D^{\prime}}}\right]-F\left(\lambda_{i}, D^{\prime}, t\right)
$$

where

$$
\begin{aligned}
(R / B)_{i}= & \text { Ratio of release rate to birth rate of isotope } i \text {, } i . e \text {. the } \\
& \text { fraction of nuclide } i \text { generated in the particle which is } \\
& \text { released. } \\
\lambda_{i}= & \text { decay constant }(1 / \mathrm{sec}) \text { of } 1 \text { sotope } i \\
D^{\prime}= & \text { diffusion parameter }(1 / \mathrm{sec}) \text { characteristic of the chemical } \\
& \text { element of which isotope } i \text { is a member. } D^{\prime} \text { for failed fuel } \\
& \text { is appreciably greater than that for intact fuel, and is also } \\
& \text { a strong function of temperature. } \\
F\left(\lambda_{i}, D^{\prime}, t\right)= & \text { the time dependent part of } R / B . \text { It is a series summation. } \\
& \text { See Eq. } 9 \text { of Reference } 4 . \\
t= & \text { irradiation time, sec. }
\end{aligned}
$$


The steady state or equilibrium $R / B, R / B_{\infty}$

$$
(R / B)_{i, \infty}=\frac{3}{\sqrt{\lambda_{i} / D^{\prime}}}\left[\operatorname{coth} \sqrt{\lambda_{i} / D^{\prime}}-\frac{1}{\sqrt{\lambda_{i} / D^{\prime}}}\right]
$$

is assumed applicable to all the noble gas fission products except ${ }^{85} \mathrm{Kr}$ which has a $10.74 \mathrm{yr}$. hal.f life.

For some combinations of the values of $\lambda_{i}, D^{\prime}$ and $t$, the time dependent part of equation $12, F\left(\lambda_{i}, D^{\prime}, t\right)$, is not readily calculable because. of slow convergence. Reference 4 shows that under these conditions equation 12 approaches (i.e. the "true" value is equal to or less than) either

$$
(R / B)_{i} \approx 3\left[\frac{\operatorname{erf} \sqrt{\lambda_{i} t}}{\sqrt{\lambda_{i} / D^{\prime}}}-\left(\frac{1-e^{-\lambda_{i} t}}{\lambda_{i} / D^{\prime}}\right)\right]
$$

or

$$
(\mathrm{R} / \mathrm{B})_{i} \approx 6 \sqrt{\frac{D^{\prime} t}{\pi}}-3 D^{\prime} t
$$

In calculating the $R / B$ for ${ }^{85} \mathrm{Kr}$, the program calculates the $\mathrm{R} / \mathrm{B}$ using each of equations 13,14 , and 15 , and selects the smallest value as being the approximate "true" value. Figure 1 is a comparison of the ${ }^{85} \mathrm{Kr}$ $\mathrm{R} / \mathrm{B}$ for $1 \%$ failed fuel as calculated from the steady state formula (Eq. 13), from the approximation equatione 14 and 15 , and from the "true" valueequation 12 -- as tabulated in Table 2 of Reference 4. In this case, the computer would select the equation 14 value as being the approximation to the equation 12 value.

At the start of an equilibrium cycle of the reactor (after the fourth year of operation), one fourth of the fuel in the reactor is fresh fuel, another fourth has been in the reactor for one year, another fourth has been in two years, and the balance three years. For sake of conservatism, the program calculates the $R / B$ of ${ }^{85} \mathrm{Kr}$ at the end of the equilibrium cycle, i.e., just before the annual refueling. Thus one fourth of the core has 
been irradiated for approximately 1 year, another fourth for 2 years, another fourth for three years, and the balance for four years. This results in the maximum realistic value of $\mathrm{R} / \mathrm{B}$ for ${ }^{85} \mathrm{Kr}$.

General Atomic Company personnel recognize that this model for $R / B$ is a gross oversimplification, but they say that it results in reasonable harmony with reality and that it has the additional advantage of relative simplicity.

Data from many inpile fuel test experiments were analyzed ${ }^{5}$ in order to develop experimental values of $D^{\prime}$. Typical results of 85 "' $\mathrm{Kr} \mathrm{K} / \mathrm{B}$ as a function of reciprocal 1rradiation, temperature is shown ill Fig. 4-2.

It is obvious that the $R / B$ vs $1 / T$ curve can be split into two components, a higher component $(H)$ and a lower component (L). I'his varlation of $\mathrm{R} / \mathrm{B}$ vs reciprocal absolute temperature can be represented mathemarleally by

$$
\mathrm{R} / \mathrm{B}\left(\mathrm{T}, \mathrm{T}_{\mathrm{O}}\right)=(\mathrm{R} / \mathrm{B})_{\mathrm{L}}^{0} \exp \left[\frac{\mathrm{QL}}{\mathrm{R}}\left(\frac{1}{\mathrm{~T}_{\mathrm{O}}}-\frac{1}{\mathrm{~T}}\right)\right]+(\mathrm{R} / \mathrm{B})_{\mathrm{H}}^{0} \exp \left[\frac{\mathrm{OH}}{\mathrm{R}}\left(\frac{1}{\mathrm{~T}_{\mathrm{O}}}-\frac{1}{\mathrm{~T}}\right] .\right.
$$

where

$$
\begin{aligned}
& \mathrm{R} / \mathrm{B}\left(\mathrm{T}, \mathrm{T}_{0}\right)=\text { katio release rate tu bitth rate at tempcrature } \mathrm{T}\left({ }^{\mathrm{O}} \mathrm{K}\right) \\
& \mathrm{T}=\text { Irradiation temperature }\left({ }^{\circ} \mathrm{K}\right) \\
& \begin{aligned}
\mathrm{I}_{0} & =\text { Reference temperature }\left(1373^{\circ} \mathrm{K}\right) \\
(\mathrm{R} / \mathrm{B})_{\mathrm{L}}^{\mathrm{O}},(\mathrm{R} / \mathrm{B})_{\mathrm{H}}^{\mathrm{O}^{\circ}} & \text { - The respective value of } \mathrm{R} / \mathrm{B} \text { at the reference tempera- }
\end{aligned} \\
& \text { Lurt fivil extrapolation of tho Lower (or Higher) } \\
& \text { branch of the curve. } \\
& Q_{L}, Q_{H}=\text { The respertive artivation energy (proportional } \\
& \text { to the slope of the respective curves with respect } \\
& \text { to reciprocal absolute temperature). } \\
& \mathrm{R}=\text { Molar gas constant. }
\end{aligned}
$$

The values of the constants in equation 16 typical of fuel that would be used for the VHTR under discussion given in Table 4-1. 
ORNL-DWG 77-12891

TEMPERATURE $\left({ }^{\circ} \mathrm{C}\right)$

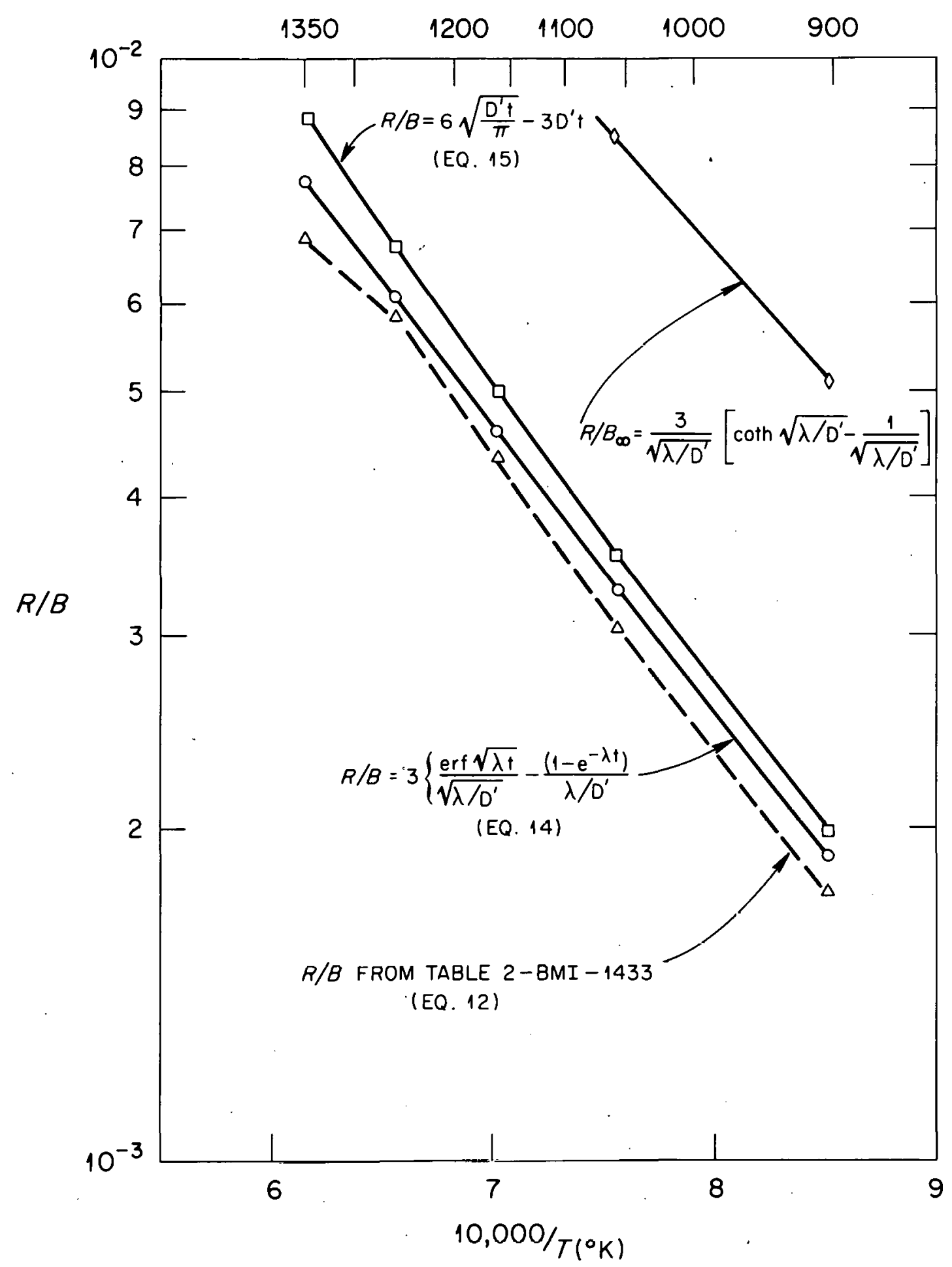

Fig. 4-1. $\mathrm{Kr}-85 \mathrm{R} / \mathrm{B}$ vs $\frac{1}{\mathrm{~T}}\left({ }^{\circ} \mathrm{K}\right)$ for $1 \%$ Falled Fuel, 2 Year Irradiation 


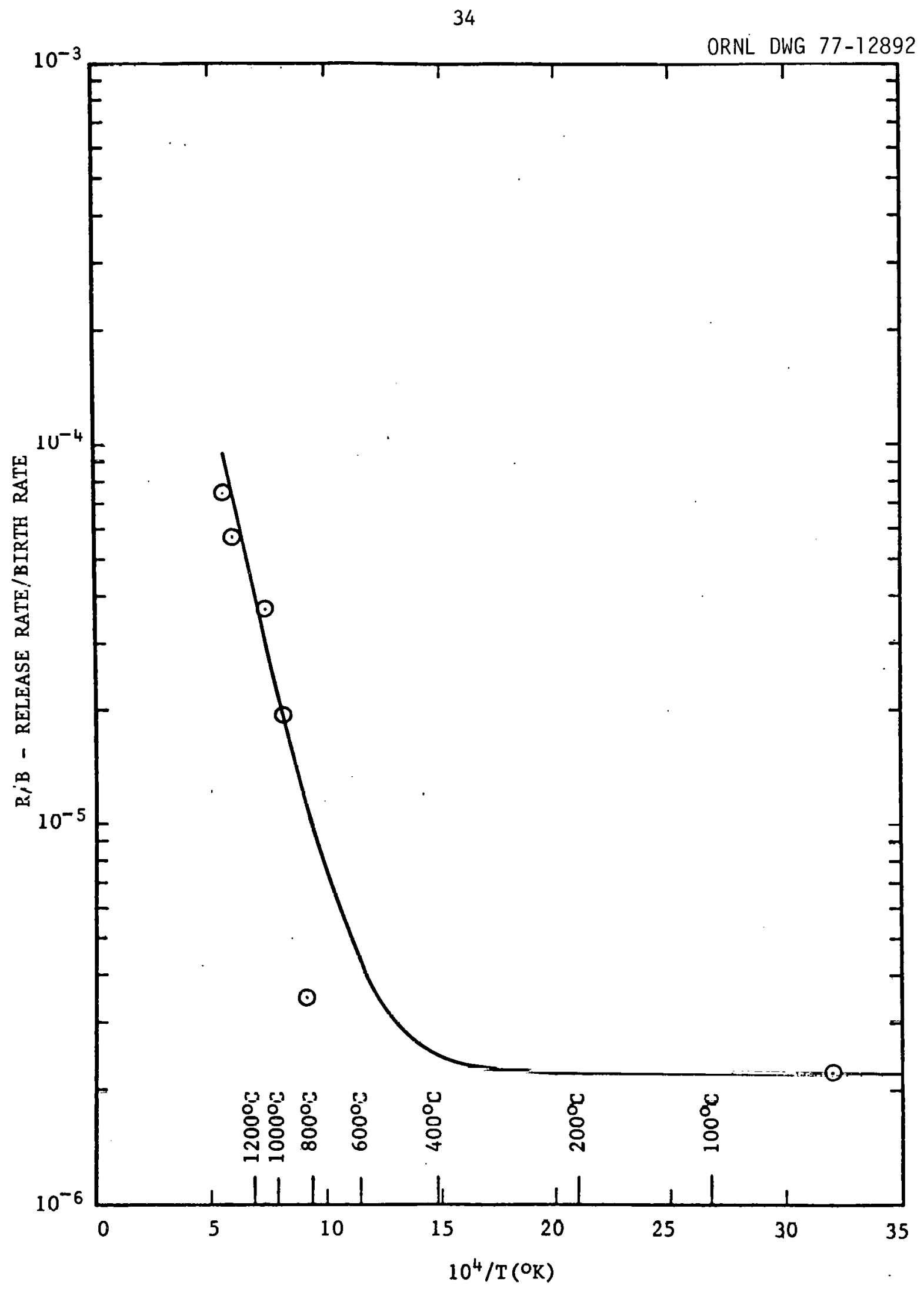

Fig. 4-2. $\mathrm{Kr}-85 \mathrm{~m} \mathrm{R/B}$ temperature dependence of Fort St. Vrain Fue1 


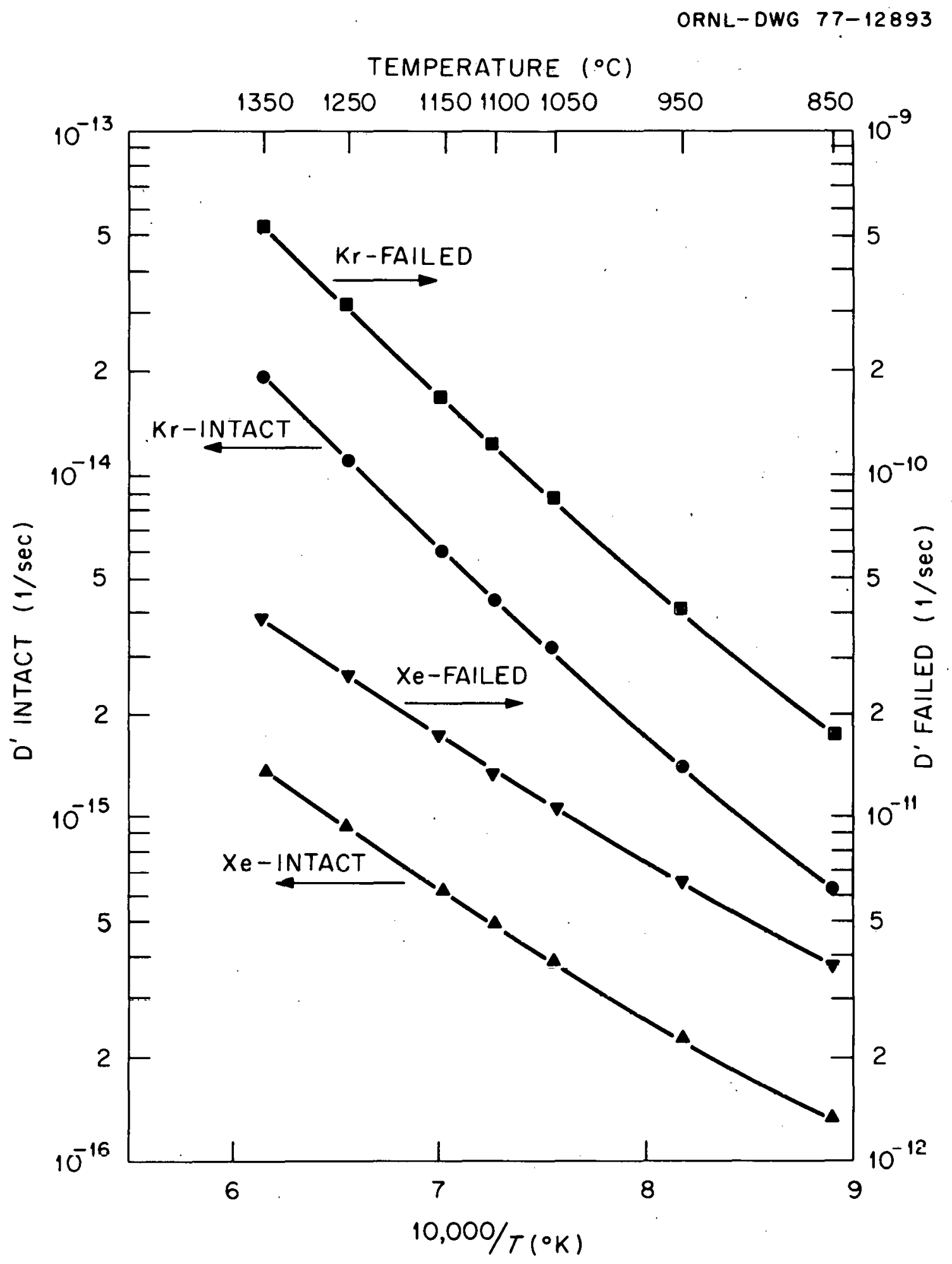

Fig. 4-3. $\mathrm{Kr}$ and $\mathrm{Xe} \mathrm{D}^{\prime}$ vs $\frac{1}{\mathrm{~T}}$ for Intact and Failed Fuel 
Table 4-1

Values of $R / B^{\circ}$ and Activation Energies, $Q$, for Krypton and Xenon

\begin{tabular}{|c|c|c|c|c|c|c|}
\hline & \multicolumn{3}{|c|}{$\mathrm{Kr}$} & \multicolumn{3}{|c|}{$\mathrm{Xe}$} \\
\hline & \multirow{3}{*}{$(\mathrm{R} / \mathrm{B})^{\circ}$} & \multicolumn{2}{|c|}{$\mathrm{Q}$} & \multirow{3}{*}{$(R / B)^{\circ}$} & \multicolumn{2}{|c|}{$Q$} \\
\hline & & calories & joules & & calories & joules \\
\hline & & gm-mole & gm-mole & & gm-mole & gm-mole \\
\hline Lower Branch & $3.0 \times 10^{-6}$ & 800 & 3350 & $5 \times 10^{-7}$ & 800 & 3350 \\
\hline Higher Branch & $2.7 \times 10^{-5}$ & 1400 & 5860 & $1.8 \times 10^{-6}$ & 1100 & 4600 \\
\hline
\end{tabular}

$\mathrm{T}=1373^{\circ} \mathrm{K}\left(1100^{\circ} \mathrm{C}\right)$

$\mathrm{R}=8.3144$ joules per gm-mole per ${ }^{\circ} \mathrm{K}, 1987$ calories per $\mathrm{gm}$-mole per ${ }^{\circ} \mathrm{K}$.

Corresponding values of $D^{\prime}$ as a function of temperature can be obtained by using the above constants in equation 16 in conjunction with equation 13. The values obtained for $D^{\prime}$ at the reference temperature $1373^{\circ} \mathrm{K}\left(1100^{\circ} \mathrm{C}\right)$ are shown in Table 4-2.

Table 4-2

Values of $D^{\prime}$ at $1373^{\circ} \mathrm{K}\left(1100^{\circ} \mathrm{C}\right)$

\begin{tabular}{lll} 
& Intact Fuel & Failed Fuel \\
\hline $\mathrm{Kr}$ & $4.38 \times 10^{-15} \mathrm{sec}^{-1}$ & $1.22 \times 10^{-10} \mathrm{sec}^{-1}$ \\
$\mathrm{Xe}$ & $4.86 \times 10^{-16} \mathrm{sec}^{-1}$ & $1.37 \times 10^{-11} \mathrm{sec}^{-1}$ \\
\hline
\end{tabular}

Figure 4-3 is a plot of $D^{\prime}$ for $K r$ and $X e$ vs $1 / T(K)$ for intact and failed fuel as used in the computer program to calculate the $R / B$ of the fuel.

Most of the other input parameters to the computer program are similar to those used for the Fulton Generating Station since, as mentioned earlier, the VHTR used in the current study is a modification of the Fulton HTGR. Values of the various input parameters are listed in Table 4-3, along with basis for change when they differ from Fulton 
values. Most of the Fulton data were obtained from Table 1.3.12 of the Fulton Generating Station Preliminary Safety Analysis Report. The "failed fuel fraction" was assumed to be constant with time and equal to $1.0 \%$ for the core average. This is conservative, since according to Chapter 7 of Reference 6 and Table 4-2 of Reference 1, the "expected" failed fuel fraction (0.268\%) is attained just before the shutdown for annual fuel reloading, and the time averaged value (throughout the whole irradiation year) $=0.22 \%$. Thus these results, as far as fraction of failed fuel is concerned, are conservative by a factor of about four.

Another important factor in determining the primary coolant fission product activity is the primary coolant turnover time, i.e., the ratio of active helium inventory to purification system flow rate ( $1 \mathrm{~b} / 1 \mathrm{~b}$ per hr or hrs).

Tables 4-4, 4-5, and 4-6 list the noble gas and iodine fission product activity and concentration in the primary coolant as calculated by the computer code using the parameters listed in Table 4-3 and a failed fuel fraction 0.01 . 
TABLE 4-3

VHTR CORPUTER PRCGRAM PARAMETER COMPARISON

'WITH FULTON GENERATING STATION

\begin{tabular}{|c|c|c|c|c|}
\hline Parameter & Units & VHTR & Fulton & Basis \\
\hline Core Power & MWt & 3,000 & 3,000 . & \\
\hline $\begin{array}{r}\text { Fuel Temp. - Avg. } \\
\text { Max. }\end{array}$ & $\begin{array}{l}a_{F} \\
a_{F}\end{array}$ & $\begin{array}{l}1,698 \\
2,475\end{array}$ & $\begin{array}{l}1,634 \\
2,570\end{array}$ & $\begin{array}{l}\text { T.abミe 6-4, Ref. } 3 \\
\text { T.ab=e. } 6-4 \text {, Ref. } 3\end{array}$ \\
\hline $\begin{array}{c}\text { Nocierator Temperature } \\
\text { AvE. } \\
\text { Max. }\end{array}$ & $\frac{C_{F}}{C_{F}}$ & $\begin{array}{l}1,541 \\
2,273\end{array}$ & $\begin{array}{l}1,362 \\
2,088\end{array}$ & $\begin{array}{l}\text { Tat:e } 6-4, \operatorname{Ref} .3 \\
\text { Tabie } 6-4, \operatorname{Ref} .3\end{array}$ \\
\hline Prinary Helium Elow & $\mathrm{lb} / \mathrm{hr}$ & $9.93 \times 10^{6}$ & $10.84 \times 10^{6}$ & Tak:e 6.4, Ref. 3 \\
\hline $\begin{array}{l}\text { Primary Helfum Teap. } \\
\text { Reactor Inlet } \\
\text { Reactor Outlet }\end{array}$ & $c_{F}^{c_{F}}$ & $\begin{array}{l}770 \\
1,600\end{array}$ & $\begin{array}{l}606 \\
1,392\end{array}$ & $\begin{array}{l}\text { Tab:e 6-4, Ref. } 3 \\
\text { Tay-e 6-4, Ref. } 3\end{array}$ \\
\hline Active Helium Irventory & 1b & 15,000 & 20,700 & $\begin{array}{l}\text { Sadie up from Sumit } \\
\text { (F.j-ton Fig. in erros) }\end{array}$ \\
\hline Fuel Irradiatior Iime & $\mathrm{yr}$ & 4 & 4 & Tyide 6-4, Ref. 3 \\
\hline $\begin{aligned} \text { Steam Flow - } & \text { Main } \\
& \text { Reteat }\end{aligned}$ & $\begin{array}{l}\text { Ib } / \mathrm{hr} \\
\text { Ib } / \mathrm{hr}\end{array}$ & $4.45 \times 10^{6}$ & $\begin{array}{l}8.05 \times 10^{6} \\
7.97 \times 10^{6}\end{array}$ & Calculated \\
\hline Steam Temperature & ${ }^{c_{F}}$ & 955 & 955 & Pg. 5-16, Ref. 2 \\
\hline
\end{tabular}


TABLE 4-4 NOBLE GAS FISSIDN PRODUCT ACTIVITY IN PRIMARY

COOLANT OF A 3000 MWE VHTR

AS A FUNCTION OF HELIUM PURIFICATION SYSTEM FLOW

\begin{tabular}{|c|c|c|c|c|c|c|c|}
\hline \multirow{2}{*}{\multicolumn{3}{|c|}{ ISOTOPE - HALF LIFE }} & \multicolumn{5}{|c|}{ Fission Product Activity (Ci) } \\
\hline & & & $\begin{array}{l}\text { Turnover } \\
\text { Time-Hrs. }{ }^{\circ} \quad \infty\end{array}$ & 15.0 & 7.5 & 5.0 & 3.75 \\
\hline $\begin{array}{r}\mathrm{Rr}-83 \mathrm{M} \\
-85 \mathrm{M} \\
-85\end{array}$ & $\begin{array}{c}1.85 \\
4.4 \\
10.74\end{array}$ & $\begin{array}{l}\mathrm{H} \\
\mathrm{H} \\
\mathrm{Y}\end{array}$ & $\begin{array}{l}1.15(3) \\
2.26(3) \\
1.53(3)\end{array}$ & $\begin{array}{l}9.72(2) \\
1.59(3) \\
3.33\end{array}$ & $\begin{array}{l}8.44(2) \\
1.23(3) \\
1.66\end{array}$ & $\begin{array}{l}7.45(2) \\
9.96(2) \\
1.10\end{array}$ & $\begin{array}{l}6.68(2) \\
8.41(2) \\
0.83\end{array}$ \\
\hline $\begin{array}{l}-87 \\
-88 \\
-89\end{array}$ & $\begin{array}{c}76 \\
2.79 \\
3.18\end{array}$ & $\begin{array}{l}M \\
H \\
M\end{array}$ & $\begin{array}{l}2.16(3) \\
3.96(3) \\
6.43(2)\end{array}$ & $\begin{array}{r}1.92(3) \\
3.12(3) \\
\circ \quad 6.40(2)\end{array}$ & $\begin{array}{l}1.74(3) \\
2.58(3) \\
6.37(2)\end{array}$ & $\begin{array}{l}1.58(3) \\
2.19(3) \\
6.33(2)\end{array}$ & $\begin{array}{l}1.45(3) \\
1.91(3) \\
6.30(2)\end{array}$ \\
\hline $\begin{array}{l}\mathrm{Xe}-131 \mathrm{M} \\
-133 \mathrm{M} \\
-133\end{array}$ & $\begin{array}{r}11.96 \\
2.26 \\
5.27\end{array}$ & $\begin{array}{l}D \\
D \\
D\end{array}$ & $\begin{array}{l}1.74(2) \\
3.96(2) \\
2.21(4)\end{array}$ & $\begin{array}{l}6.09 \\
6.38(1) \\
1.66(3)\end{array}$ & $\begin{array}{l}3.10 \\
3.47(1) \\
8.59(2)\end{array}$ & $\begin{array}{l}2.08 \\
2.38(1) \\
5.79(2)\end{array}$ & $\begin{array}{l}1.56 \\
1.81(1) \\
4.38(2)\end{array}$ \\
\hline $\begin{array}{l}-135 M \\
-135 \\
-137 \\
-138\end{array}$ & $\begin{array}{c}15.7 \\
9.16 \\
3.8 i \\
14.2\end{array}$ & $\begin{array}{l}M \\
H \\
M \\
M\end{array}$ & $\begin{array}{l}1.05(3) \\
7.08(3) \\
3.12(2) \\
6.02(2)\end{array}$ & $\begin{array}{l}1.03(3) \\
3.75(3) \\
3.10(2) \\
5.89(2)\end{array}$ & $\begin{array}{l}1.00(3) \\
2.55(3) \\
3.09(2) \\
5.76(2)\end{array}$ & $\begin{array}{l}9.80(2) \\
1.92(3) \\
3.07(2) \\
5.64(2)\end{array}$ & $\begin{array}{l}9.58(2) \\
1.55(3) \\
3.05(2) \\
5.52(2)\end{array}$ \\
\hline $\begin{array}{l}\text { Noble } \\
\text { Gas F.P. }\end{array}$ & & & $4.34(4)$ & $1.57(4)$ & $1.24(4)$ & $1.05(4)$ & $0.93(4)$ \\
\hline $\begin{array}{l}\text { Noble Gas } \\
\text { +Act. Prod. }\end{array}$ & & & $4.40(4)$ & $1.63(4)$ & $1.30(4)$ & $1.11(4)$ & $0.99(4)$ \\
\hline
\end{tabular}

${ }_{\text {Turnover Time }}=\frac{\text { Active Primary Helium Inventory (1b) }}{\text { Helium Purification System Flow Rate (1b/hr) }}$

$1.85(-5)=1.85 \times 10^{-5}$. 
TABLE 4-5 NUBLE GAS FISSION PRODUCT CONCENTRATION IN PRIMARY COOLANT OF A 3000 MWt VHTR AS A FUNCTION OF HELIUM PURIFICATION SYSTEM FLOW

\begin{tabular}{|c|c|c|c|c|c|c|c|}
\hline \multirow[t]{2}{*}{ ISOTOPE - } & \multirow[t]{2}{*}{ - HALF LIFE } & \multicolumn{6}{|c|}{ Fission Product Concentration ( $\mu \mathrm{Ci} / \mathrm{std}$. CC) } \\
\hline & & & $\begin{array}{l}\text { Turiuver } \\
\text { Time Hrs. }\end{array}$ & 15.0 & 7.5 & 5.0 & 3.75 \\
\hline $\begin{array}{r}K r-83 M \\
-85 M \\
-85\end{array}$ & $\begin{array}{c}1.86 \\
4.4 \\
10.74\end{array}$ & $\begin{array}{l}\mathbf{H} \\
\mathbf{H} \\
\mathrm{H}\end{array}$ & $\begin{array}{l}3.0(-2) \\
5.9(-2) \\
4.0(-2)\end{array}$ & $\begin{array}{l}2.6(-2) \\
4.2(-2) \\
8.7(-5)\end{array}$ & $\begin{array}{l}2 \cdot 2(-2) \\
3 \cdot 2(-2) \\
4 \cdot 4(-5)\end{array}$ & $\begin{array}{l}2.0(-2) \\
2.6(=2) \\
2.9(-5)\end{array}$ & $\begin{array}{l}1.8(-2) \\
2.2(-2) \\
2.2(-5)\end{array}$ \\
\hline $\begin{array}{l}-87 \\
-88 \\
-89\end{array}$ & $\begin{array}{l}76 \\
2.79 \\
3.18\end{array}$ & $\begin{array}{l}\text { M } \\
\mathbf{H} \\
\mathbf{M}\end{array}$ & $\begin{array}{l}5.7(-2) \\
1.0(-1) \\
1.7(-2)\end{array}$ & $\begin{array}{l}5.0(-2) \\
8.2(-2) \\
1.7(-2)\end{array}$ & $\begin{array}{l}4.6(-2) \\
6.8(-2) \\
1.7(-2)\end{array}$ & $\begin{array}{l}4.1(-2) \\
5.7(-2) \\
1.7(-2)\end{array}$ & $\begin{array}{l}3.8(-2) \\
5.0(-2) \\
1.7(-2)\end{array}$ \\
\hline $\begin{array}{r}\mathrm{Xe}-131 \mathrm{M} \\
-133 \mathrm{M} \\
-133\end{array}$ & $\begin{array}{r}11.96 \\
2.26 \\
5.27\end{array}$ & $\begin{array}{l}\text { D } \\
\text { D } \\
\text { D }\end{array}$ & $\begin{array}{l}4.6(-3) \\
1.0(-2) \\
5.8(-1)\end{array}$ & $\begin{array}{l}1.6(-4) \\
1.7(-3) \\
4.4(-2)\end{array}$ & $\begin{array}{l}8.1(-3) \\
9.1(-4) \\
2.3(-2)\end{array}$ & $\begin{array}{l}5.5(-5) \\
6.2(-4) \\
1.51(-2)\end{array}$ & $\begin{array}{l}4.1(-5) \\
4.8(-4) \\
1.1(-2)\end{array}$ \\
\hline $\begin{array}{l}-135 M \\
-135 \\
-137 \\
-138\end{array}$ & $\begin{array}{c}15.7 \\
9.16 \\
3.82 \\
1.4 .2\end{array}$ & $\begin{array}{l}\mathrm{M} \\
\mathrm{H} \\
\mathrm{M} \\
\mathrm{M}\end{array}$ & $\begin{array}{l}2.8(-2) \\
1.9(-1) \\
8.2(-3) \\
1.6(-2)\end{array}$ & $\begin{array}{l}2.7(-2) \\
9.8(-2) \\
8.1(-3) \\
1.5(-2)\end{array}$ & $\begin{array}{l}2.6(-2) \\
6.7(-2) \\
0.1(-3) \\
1.5(-2)\end{array}$ & $\begin{array}{l}2.6(-2) \\
5.0(-2) \\
8.1(3) \\
1.5(-2)\end{array}$ & $\begin{array}{l}2.5(-2) \\
4.1(-2) \\
8.0(-3) \\
1.4(-2)\end{array}$ \\
\hline Nulle Gas & s T. T & & $1.1 \dot{4}$ & 0.11 & 0.33 & 0.78 & 0.24 \\
\hline Noble Gas & $s+$ Act. $\operatorname{Pr}$ & od & 1.15 & 0.43 & 0.34 & 0.29 & 0.26 \\
\hline
\end{tabular}


TABLE 4-6 TODINE FISSION PRODUCT ACTIVITY AND CONCENTRATION IN PRIMARY COOLANT OF A 3000 MWE VHTR VS. HELIUM PURIFICATION SYSTEM FLOW

\begin{tabular}{|c|c|c|c|c|c|c|c|}
\hline \multirow[b]{2}{*}{ ISOTOPE } & \multirow[b]{2}{*}{ - HALF LIFE } & & \multicolumn{5}{|c|}{ Iodine Fission Product Activity (Curies) } \\
\hline & & & $\begin{array}{l}\text { Turnover } \\
\text { Time-Hrs. } \quad \infty\end{array}$ & 15.0 & $\begin{array}{r}7.5 \\
. \\
\end{array}$ & 5.0 & 3.75 \\
\hline $\begin{array}{l}I-129 \\
I-131 \\
I-132\end{array}$ & $\begin{array}{l}1.6 \mathrm{x} \\
8.065 \\
2.284\end{array}$ & $\begin{array}{c}10^{7} \mathrm{Y} \\
\mathrm{D} \\
\mathrm{H}\end{array}$ & $\begin{array}{l}6.66(-10) \\
1.048(-1) \\
1.373\end{array}$ & $\begin{array}{l}6.66(-10) \\
1.048(-1) \\
1.373\end{array}$ & $\begin{array}{l}6.65(-10) \\
1.047(-1) \\
1.373\end{array}$ & $\begin{array}{l}6.65(-10) \\
1.047(-1) \\
1.373\end{array}$ & $\begin{array}{l}6.65(-10) \\
1.047(-1) \\
1.372\end{array}$ \\
\hline $\begin{array}{l}I-133 \\
I-134 \\
I-135 \\
I-136\end{array}$ & $\begin{array}{r}20.8 \\
52.3 \\
6.7 \\
85 \mathrm{~S}\end{array}$ & $\begin{array}{l}\mathrm{H} \\
\mathrm{M} \\
\mathrm{H}\end{array}$ & $\begin{array}{l}6.127(-1) \\
3.288 \\
9.453(-1) \\
9.509\end{array}$ & $\begin{array}{l}6.126(-1) \\
3.288 \\
9.451(-1) \\
9.507\end{array}$ & $\begin{array}{l}6.125(-1) \\
3.287 \\
9.449(-1) \\
9.505\end{array}$ & $\begin{array}{l}6.123(-1) \\
3.286 \\
9.447(-1) \\
9.503\end{array}$ & $\begin{array}{l}6.122(-1) \\
3.286 \\
9.445(-1) \\
9.501\end{array}$ \\
\hline
\end{tabular}

Iodine Fission Product Concentration $\mu \mathrm{C} 1 / \overline{\mathrm{S}} \mathrm{dd} . \mathrm{CC}$

\begin{tabular}{|c|c|c|c|c|c|c|c|c|}
\hline $\begin{array}{l}I-129 \\
I-131 \\
I-132\end{array}$ & - & $\begin{array}{l}1.6 \times \\
8.065 \\
2.284\end{array}$ & $\begin{array}{c}10^{7} \mathrm{Y} \\
\mathrm{D} \\
\mathrm{H}\end{array}$ & $\begin{array}{l}1.7(-14) \\
2.8(-6) \\
3.6(-5)\end{array}$ & $\begin{array}{l}1.7(-14) \\
2.8(-6) \\
3.6(-5)\end{array}$ & $\begin{array}{l}1.7(-14) \\
2.7(-6) \\
3.6(-5)\end{array}$ & $\begin{array}{l}1.7(-14) \\
2.7(-6) \\
3.6(-5)\end{array}$ & $\begin{array}{l}1.7(-14) \\
2.7(-6) \\
3.6(-5)\end{array}$ \\
\hline $\begin{array}{l}I-133 \\
I-134 \\
I-135\end{array}$ & & $\begin{array}{r}20.8 \\
52.3 \\
6.7\end{array}$ & $\begin{array}{l}\mathrm{H} \\
\mathrm{M} \\
\mathrm{H}\end{array}$ & $\begin{array}{l}1.6(-5) \\
8.6(-5) \\
2.5(-5)\end{array}$ & $\begin{array}{l}1.6(-5) \\
8.6(-5) \\
2.5(-5)\end{array}$ & $\begin{array}{l}1.6(-5) \\
8.6(-5) \\
2.5(-5)\end{array}$ & $\begin{array}{l}1.6(-5) \\
8.6(-5) \\
2.5(-5)\end{array}$ & $\begin{array}{l}1.6(-5) \\
8.6(-5) \\
2.5(-5)\end{array}$ \\
\hline$I-136$ & & 85 & & $2.5(-4)$ & $2.5(-4)$ & $2.5(-4)$ & $2.5(-4)$ & $2.5(-4)$ \\
\hline
\end{tabular}




\section{References}

1. M. J. Haire and D. W. McEachern, Gaseous Radioactivity Levels in the Primary Coolant of an HTGR, General Atomic Co., GA-A12946, Oct. 1, 1974.

2. F. E. Vanslager, RAD-2, A Computer Program for Calculating Fission Product Radioactivities, USAEC Report GAMD-6519, General Dynamics, General Atomic Division, 1965.

3. Fulton Generating Station Units 1 and 2, Preliminary Safety Analysis Report, Section 9.3.1; Philadelphia Electric Co.

4. S. D. Beck, The Diffusion of Radioactive Fission Products from Porous Fuel Elements, BMI-1433, Battelle Memorial Institute, April 1960.

5. Personal Communication, Ben Meyers, General Atomics Co., January 1976.

6. A. S. Shenoy, D. W. McEachern, et al., HTGR Core Therma1 Design Methods and Analysis, GA-A12985, General Atomic Co., Dec. 31, 1974.

\section{Figures}

4-1 Calculated $\mathrm{Kr}(\mathrm{R} / \mathrm{B})$ for $1 \%$ Failed Fuel vs $1 / \mathrm{T}$ ( ${ }^{\mathrm{K}}$ ) for 2 years Irradiation.

4-2 $85 \mathrm{~m}_{\mathrm{Kr}} \mathrm{R} / \mathrm{B}$ temperature dependence of Fort St. Vrain fuel (Fig. 4-2 of $\mathrm{GA}-\mathrm{A} 12946)$.

4-3 $\mathrm{D}^{\prime}$ for $\mathrm{Kr}$ and $\mathrm{Xe}$ vs $1 / \mathrm{T}\left({ }^{\circ} \mathrm{K}\right)$ for Intact and Failed Fuel.

Tables

4-3 VHTR Computer Program Parameter Comparison with Fulton Generating Station.

4-4. Noble Gas Fisșion Product Activity in Primary Coolant of a 3000 MWt VHGTR as a Function of Helium Purification System Flow.

4-5 Noble Gas Fission Product Concentration in Primary Coolant of a 3000 MWt VHGTR as a Function of Helium Purification System Flow.

4-6 Iodine Fission Product Activity and Concentration in Primary Coolant of a 3000 MWt VHTGR vs Helium Pufification System Flow. 
V. NOBLE GAS AND IODINE FISSION PRODÚCT RELEASE TO THE ENVIRONMENT

The normal noble gas and iodine fission "product release to the environment by the VHTR under study is similar to that of a similar sized HTGR. The principal pathways are by primary coolant leaks through the PCRV to the containment and the controlled release of accumulated processed (i.e., decayed) gas, mostly ${ }^{85} \mathrm{Kr}$, from the regeneration of the noble-gas retention section of the helium purification system.

Tables 5-1 through 5-4 lists the noble gas and iodine fission products calculated releases to the environment via:

1) Waste Gas Processing System - primarily from regeneration of the helium purification system;

2) Steam Jet Air Ejector - practically no release because steam pressure in steam generator is higher than primary coolant, thus no normal leak from the primary coolant to steam.

3) Prestressed Concrete Reactor Vessel - based on the primary leakage rate thru the PCRV assumed by the U.S. Nuclear Regulatory Commission, $800 \mathrm{lb} / \mathrm{yr}$ for Fulton.

4) Turbine Building Leak - is negligible because of the low secondary (steam) activity;

5) Service Building Leak - is smal1 - one of the hydrogen removal processes in the helium purification system (as used by GA) occurs in the service building. .

To more clearly show the effect of the helfum purification turnover time upon the noble gas and iodine fission products release to the environs, Table 5-5 summarizes the total release via each route as a function of the turnover time.

The doses associated with the above releases to the environment have not been calculated because they are very site dependent (meteorology, exclusion boundary distance, etc.). However, under any normal conditions, 
the releases are so low that there should be no difficulty in meeting statutory requirements.

There is a possibility of leakage of the primary coolant through the reformer into the process stream since the primary coolant pressure is greater than that of the process stream in the reformer. Thus it is possible for the plant product (hydrogen with a small amount of methane) to become contaminated with noble gas and iodine fission products. While normal leak rates from the primary system to the reformer have not been established, reasonable rates can be assumed for the purpose of estimating the dose to users of the product gas.

of the many possible usages of the product, the one that may give the highest dose rate to people would be the use of the product gas in a 50/50 mix (an assumed upper limit for the fraction of hydrogen in gas for home use) with natural gas in unvented kitchen ranges in the home (space and hot water heaters are required to be vented). If one assumes an $800 \mathrm{lb} / \mathrm{yr}$ (363 kg/yr) primary coolant to product leak rate (the same as the primary leak rate through the PCRV) and a turnover time of 5 hrs., then the noble gas fission product activity in the system includes ${ }^{85} \mathrm{Kr}, 1.1 \mathrm{Ci}$; ${ }^{131} \mathrm{~m}^{\mathrm{Xe}}$, $2.1 \mathrm{C} 1{ }^{13} \mathrm{~m}_{\mathrm{Xe}}, 23.8 \mathrm{Ci}$; and $133 \mathrm{Xe}, 579 \mathrm{Ci}$ (Table 4-4). The total activity remaining after a 3.5 day decay period is $376 \mathrm{Ci}$, of which $365 \mathrm{Ci}$ is due to ${ }^{133} \mathrm{xe}$.

The 3.5 day period is an assumed time for processing the gas and for sending it through gas transmission lines to users. Barton, Moore and Hanna ${ }^{1}$ calculated a dilution factor of 7540 for the unvented kitchen range.

The following assumptions were made in calculating the concentration of noble gas activity in a home using natural gas for cooking:

$$
\begin{aligned}
376 \mathrm{Ci}= & \text { Reactor loop activity } \\
1.46 \times 10^{-4} / \mathrm{da}= & \text { leakage rate from reactor loop into } \\
& \text { reformer, i.e. } 8001 \mathrm{bs} . / \mathrm{yr} \text { from } 15,0001 \mathrm{~b} \\
& \text { loop inventory }
\end{aligned}
$$


$8.22 \times 10^{8} \mathrm{ft}^{3} / \mathrm{da}=\mathrm{H}_{2}$ production per $\mathrm{day}^{2}$

$50 / 50 \mathrm{mix}$ of product gas with natural gas

$7540=$ dilution factor in home

The noble gas activity in the house is $1.56 \times 10^{-13} \mu \mathrm{Ci} / \mathrm{cm}^{3}$.

The dose conversion factor given in Ref. 3 is $0.132 \times 10^{10} \mathrm{millirem} / \mathrm{yr}$ for $1 \mu \mathrm{Ci} / \mathrm{cm}^{3}$. This gives a dose of $2 \times 10^{-4} \mathrm{millirem} / \mathrm{yr}$ to occupants of the home for 365 days/yr. This is about $2 \times 10^{-4} \%$ of the average U.S. dose from background radiation.

To help bring the foregoing dose into perspective, it is estimated that the whole body dose from cosmic rays varies from $35 \mathrm{millirem} / \mathrm{yr}$ at sea level to about $80 \mathrm{millirem} / \mathrm{yr}$ (7000 $\mathrm{ft}$. elevation above sea leve1), or an average of $6.4 \times 10^{-3}$. millirem/yr per $\mathrm{ft}$. change in elevation. Thus the $2 \times 10^{-4} \mathrm{millirem} / \mathrm{yr}$ dose represents an average annual change in elevation of approximately a half inch. Another comparison based on cosmic ray exposure is the increase in dose of $0.8 \mathrm{millirem} / \mathrm{hr}$ for a plane flight at $35,000 \mathrm{ft}$. altitude. The $2 \times 10^{-4}$ millirem/yr dose represents one $3 \times 10^{-4} \mathrm{hr}$. flight in one year, or approximately one $1-\mathrm{sec}$. flight per year. Thus the assumed leak rate from the primary coolant to the product of $363 \mathrm{~kg} / \mathrm{yr}(800 \mathrm{lb} / \mathrm{yr})$ could be increased appreciably before a significant dose through this exposure pathway would occur.

The ${ }^{131}$ I concentration in air is also of some concern. The Maximull Permissible Concentration of ${ }^{131}$ I in air (MPC ${ }_{a}$ ) for population groups is $1 \times 10^{-4} \mathrm{pcoi} / \mathrm{cm}^{3}$.

In the manner described above for noble gases, ${ }^{1}$ the ${ }^{131} \mathrm{I}$ concentration in the air of a home using an unvented kitchen range was calculated to be approximately $3 . ; \times 10^{-11} \mathrm{pCi} / \mathrm{cm}^{3}$, or $3.7 \times 10^{-7}$ of $\mathrm{MPC}_{\mathrm{a}}$. Thus it appears that, from a population viewpoint, the leakage of fission products in the primary coolant into the process gas causes no problems when the gas is used in unvented kitchen ranges. 
In most cases when the hydrogen in the process gas. is involved in some chemical reaction which results in a solid or liquid product, the noble gas fission products could be separated from the product, and the product would be free from radioactive contamination except for the iodine isotopes. The iodine activity in the product would be expected to be very low, as indicated by the calculations in the previous paragraphs. 
TABLE 5-1

RADIOACTIVE EFFLUENT IN GASES FOR VHTR. TURNOVER TIME 15 HRS.

Noble Gas Releases from Large HTGR

\begin{tabular}{|c|c|c|c|c|c|c|}
\hline NUCLIDE & $\begin{array}{c}\text { WGPS } \\
(\mathrm{CI} / \mathrm{YR})\end{array}$ & $\begin{array}{c}\text { SJAE } \\
(\mathrm{CI} / \mathrm{YR})\end{array}$ & $\begin{array}{l}\text { PCRV LEAK } \\
\text { (CI/YR) }\end{array}$ & $\begin{array}{l}\text { TB LEAK } \\
\text { (CI/YR) }\end{array}$ & $\begin{array}{l}\text { SB LEAK } \\
(\mathrm{CI} / \mathrm{YR})\end{array}$ & $\begin{array}{c}\text { TOTAL } \\
\text { (CI/YR) }\end{array}$ \\
\hline KR83M & 0. & 0. & 52. & 0. & 5. & 57 \\
\hline KR85M & 0. & 1. & 85. & 0. & 8. & 93 \\
\hline KR85 & 1858. & 0. & 0. & 0. & 0. & 1858 \\
\hline KR87 & 0 & 1. & 103. & 0. & 10 . & 113 \\
\hline KR88 & 0. & 1. & 167. & 0. & 16. & 184 \\
\hline KR89 & 0. & 0. & 34. & 0. & 3. & 38 \\
\hline KR90 & 0. & 0. & 13. & 0 & 1. & 14 \\
\hline KR91 & 0. & 0. & 4. & 0. & 0. & \\
\hline XE131M & 0. & 0. & 0. & 0. & 0. & \\
\hline XE133M & 0. & 0. & 3. & 0. & 0. & \\
\hline XE133 & 0. & 1. & 88. & 0. & 8. & \\
\hline XE135M & 0. & 0. & 55. & 0 : & 5. & 60 \\
\hline XE135 & 0. & 1. & 200. & 0. & 19. & 22 \\
\hline XE137 & 0. & 0. & 17. & 0 . & 2. & 1 \\
\hline XE138 & 0. & 0. & 31. & 0. & 3. & 3 \\
\hline XE139 & 0. & 0. & 7. & 0. & 1. & \\
\hline XE140 & 0 & 0. & 3. & 0. & 0 & \\
\hline TOTAL & 1858. & 6. & 862. & 0. & 82. & 2808 \\
\hline
\end{tabular}

Airborne Iodine Releases from Large HTGR

$\begin{array}{lllllll}\text { NUCLIDE } & \begin{array}{c}\text { WGPS } \\ (\mathrm{CI} / \mathrm{YR})\end{array} & \begin{array}{c}\text { SJAE } \\ (\mathrm{CI} / \mathrm{YR})\end{array} & \begin{array}{l}\text { PCRV LEAK } \\ (\mathrm{CI} / \mathrm{YR})\end{array} & \begin{array}{l}\text { TB LEAK } \\ (\mathrm{CI} / \mathrm{YR})\end{array} & \begin{array}{l}\text { SB LEAK } \\ (\mathrm{CI} / \mathrm{YR})\end{array} & \begin{array}{c}\text { TOTAL } \\ (\mathrm{CI} / \mathrm{YR})\end{array} \\ \text { I131 } & 0.000011 & 0.000000 & 0.000056 & 0.000000 & 0.000005 & 0.000073 \\ \text { I132 } & 0.0 & 0.000000 & 0.000732 & 0.000000 & 0.000070 & 0.000802 \\ \text { I133 } & 0.0 & 0.000000 & 0.000327 & 0.000000 & 0.000031 & 0.000358 \\ \text { I134 } & 0.0 & 0.000001 & 0.001754 & 0.000000 & 0.000167 & 0.001921 \\ \text { I135 } & 0.0 & 0.000000 & 0.000504 & 0.000000 & 0.000048 & 0.000552 \\ \text { I136 } & 0.0 & 0.000002 & 0.005070 & 0.000001 & 0.000482 & 0.005555 \\ \text { TOTAL } & 0.000011 & 0.000003 & 0.008443 & 0.000002 & 0.000802 & 0.009262\end{array}$


TABLE 5-2

RADIOACTIVE EFFLUENT IN GASES FOR VHTR. TURNOVER TIME 7\%: HRS.

Noble Gas Releases from Large HTGR

\begin{tabular}{|c|c|c|c|c|c|c|}
\hline NUCLIDE & $\begin{array}{c}\text { WGPS } \\
(\mathrm{CI} / \mathrm{YR})\end{array}$ & $\begin{array}{c}\text { SJAE } \\
(\mathrm{CI} / \mathrm{YR})\end{array}$ & $\begin{array}{l}\text { PCRV LEAK } \\
(C I / Y R)\end{array}$ & $\begin{array}{l}\text { TB LEAK } \\
\text { (CI/YR) }\end{array}$ & $\begin{array}{l}S B \text { I.EAK } \\
(C I / Y R)\end{array}$ & $\begin{array}{l}\text { TOTAL } \\
\text { (CI/YR) }\end{array}$ \\
\hline KR83M & 0. & 0 . & 45. & 0. & 4. & 50. \\
\hline KK85M & 0. & 0. & 65. & 0. & 6. & 72 . \\
\hline KR85 & 1858. & 0 . & 0. & 0. & 0. & 1858. \\
\hline KR87 & 0. & 1. & 93. & 0. & 9. & 102. \\
\hline KК Кகั & $n$. & 1. & 137. & 0. & 13. & 152 \\
\hline KR89 & 0. & 0 . & 34. & 0. & 3. & 37 \\
\hline KR90 & 0. & 0. & 13. & 0 . & 1. & 14 \\
\hline KR91 & 0. & 0 . & 4. & 0. & 0 . & \\
\hline XE131M & 0. & 0. & 0. & 0. & 0. & \\
\hline XE133M & 0. & 0. & 2. & 0. & 0. & \\
\hline XE133 & 0. & 0 . & 46. & 0. & 4. & 51 \\
\hline XE135M & 0. & 0 . & 54. & 0. & 5 & 59 \\
\hline XE135 & 0. & 1. & 136. & 0. & 13. & 150 \\
\hline XE137 & 0. & 0 . & 16 & 0. & 2. & $1 \xi$ \\
\hline XE138 & 0. & 0. & 31. & 0. & 3. & 36 \\
\hline XE139 & 0. & 0 . & 6. & 0. & 1. & \\
\hline $\mathrm{XE} 140$ & 0. & 0. & 3. & 0. & 0 & \\
\hline TOTAL & 1858. & 5. & 685. & 0. & 65. & 261 \\
\hline
\end{tabular}

Airborne Iodine Releases from Large HTGR

\begin{tabular}{|c|c|c|c|c|c|c|}
\hline NUCL IDE & $\begin{array}{c}\text { WGPS } \\
(\mathrm{CI} / \mathrm{YR})\end{array}$ & $\begin{array}{c}\text { SJAE } \\
(\mathrm{CI} / \mathrm{YR})\end{array}$ & $\begin{array}{l}\text { PCRV LEAK } \\
(\mathrm{CI} / \mathrm{YR})\end{array}$ & $\begin{array}{l}\text { TB LEAK } \\
\text { (CI/YR) }\end{array}$ & $\begin{array}{l}\text { SB LEAK } \\
(\mathrm{C} \bar{I} / \bar{Y} \bar{R})\end{array}$ & $\begin{array}{l}\text { TOTAL } \\
\text { (CI/YR) }\end{array}$ \\
\hline I131 & 0.000011 & 0.000000 & 0.000056 & 0.000000 & 0.000005 & 0.000073 \\
\hline I 132 & 0.0 & 0.000000 & 0.000732 & 0.000000 & 0.000070 & 0.000802 \\
\hline I133 & 0.0 & 0.000000 & 0.000327 & 0.000000 & 0.000031 & 0.000358 \\
\hline I134 & 0.0 & 0.000001 & 0.0 .1753 & ח. ח ח ח ח ח & ก. กกกו67 & ก.กก192.1 \\
\hline I135 & 0.0 & 0.000000 & 0.000504 & 0.000000 & $0: 000048$ & 0.000552 \\
\hline I136 & 0.0 & 0.000002 & 0.005069 & 0.000001 & 0.000482 & 0.005554 \\
\hline TOTAL & 0.000011 & 0.000003 & 0.008441 & 0.000002 & 0.000802 & 0.009260 \\
\hline
\end{tabular}


TABLE $5-3$

RADIOACTIVE EFFLLUENT IN GASES FOR VHTR. TURNOVER TIME 5 HRS.

Noble Gas Releases from Large HTGR

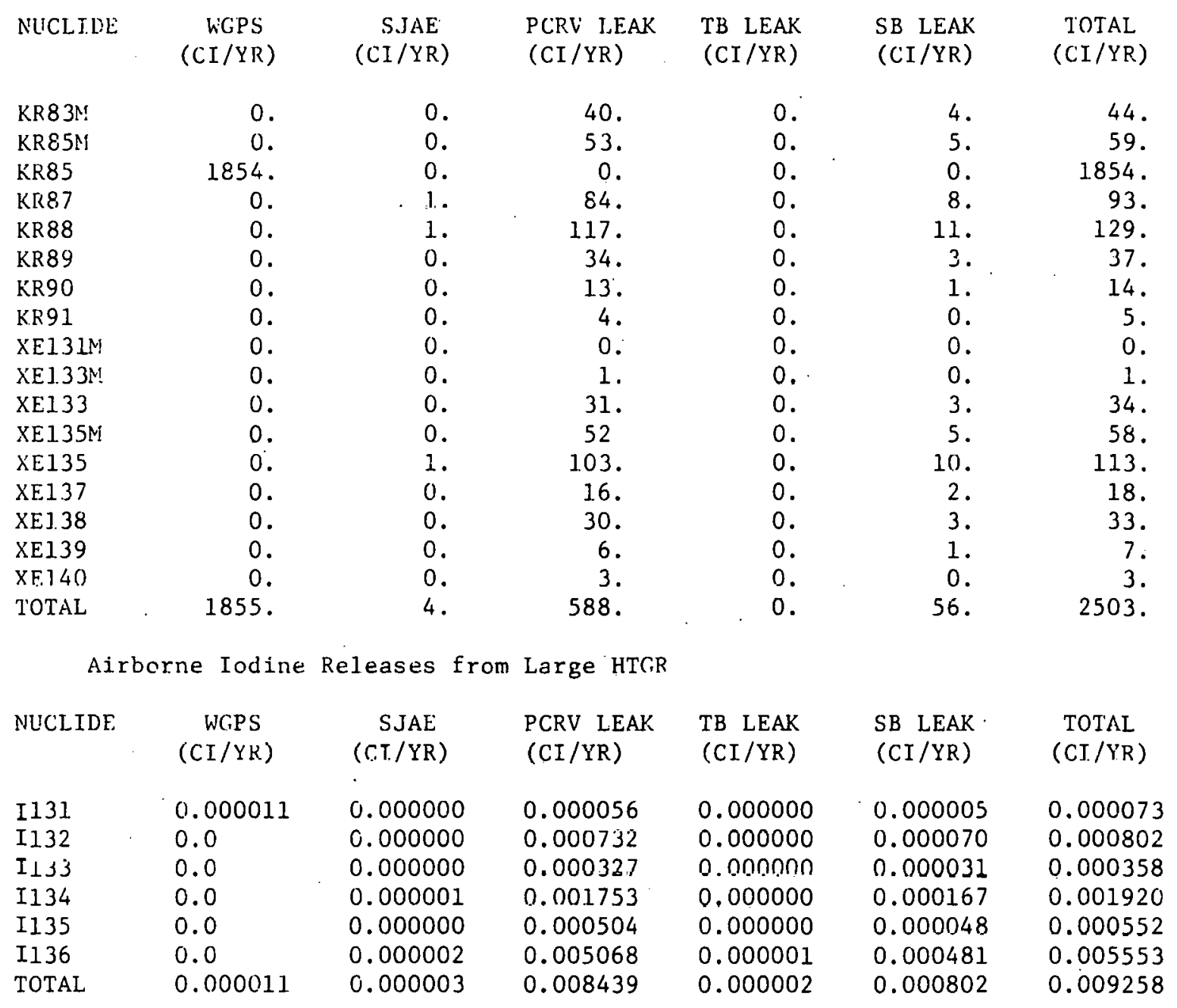


TABLE $5-4$

RADIOACTIVE EFFLUENT IN GASES FOR VHTR. TURNOVER TIME $3 \frac{3}{4}$ HRS.

Noble Gas Releases from Large HTGR

NUCLIDE WGPS

$(\mathrm{CI} / \mathrm{YR})$

SJAE
$(\mathrm{CI} / \mathrm{YR})$

PCRV LEAK

TB LEAK

SB LEAK

TOTAL

(CI/YR) (CI/YR)

(CI/YR)

(CI/YR)

$\begin{array}{lrrrrrr}\text { KR83M } & 0 . & 0 . & 36 . & 0 . & 3 . & 39 . \\ \text { KR85M } & 0 . & 0 . & 45 . & 0 . & 4 . & 49 . \\ \text { K.R85M } & 1858 . & 0 . & 0 . & 0 . & 0 . & 1858 . \\ \text { KR87 } & 0 . & 1 . & 77 . & 0 . & 7 . & 85 . \\ \text { KR88 } & 0 . & 1 . & 102 . & 0 . & 10 . & 112 . \\ \text { KR89 } & 0 . & 0 . & 34 . & 0 . & 3 . & 37 . \\ \text { KR90 } & 0 . & 0 . & 13 . & 0 . & 1 . & 14 . \\ \text { KR91 } & 0 . & 0 . & 4 . & 0 . & 0 . & 5 . \\ \text { XE131M } & 0 . & 0 . & 0 . & 0 . & 0 . & 0 . \\ \text { XE133M } & 0 . & 0 . & 1 . & 0 . & 0 . & 1 . \\ \text { XE133 } & 0 . & 0 . & 23 . & 0 . & 2 . & 26 . \\ \text { XE135M } & 0 . & 0 . & 51 . & 0 . & 5 . & 56 . \\ \text { XE135 } & 0 . & 1 . & 82 . & 0 . & 8 . & 91 . \\ \text { XE137 } & 0 . & 0 . & 16 . & 0 . & 2 . & 18 . \\ \text { XE138 } & 0 . & 0 . & 29 . & 0 . & 3 . & 32 . \\ \text { XE139 } & 0 . & 0 . & 6 . & 0 . & 1 . & 7 . \\ \text { XE140 } & 0 . & 0 . & 3 . & 0 . & 0 . & 3 . \\ \text { TOTAT. } & 1858 . & 4 . & 524 . & 0 . & 50 . & 2435 .\end{array}$

Airborne Iodine Releases from Large HTGR

$\begin{array}{lllllll}\text { I131 } & 0.000011 & 0.000000 & 0.000056 & 0.000000 & 0.000005 & 0.000073 \\ \text { I132 } & 0.0 & 0.000000 & 0.000732 & 0.000000 & 0.000070 & 0.000802 \\ \text { I133 } & 0.0 & 0.000000 & 0.000327 & 0.000000 & 0.000031 & 0.000358 \\ \text { I134 } & 0.0 & 0.000001 & 0.001752 & 0.000000 & 0.000166 & 0.001920 \\ \text { I135 } & 0.0 & 0.000000 & 0.000504 & 0.000000 & 0.000048 & 0.000552 \\ \text { I136 } & 0.0 & 0.000002 & 0.005067 & 0.000001 & 0.0 n n 481 & 0.005552 \\ \text { TOTAL } & 0.000011 & 0.000003 & 0.008438 & 0.000002 & 0.000802 & 0.009256\end{array}$


TABLE 5-5

TOTAL NOBLE GAS AND IODINE RELEASE AS A FUNCTION OF PURIFICATION SYSTEM TURNOVER TIME

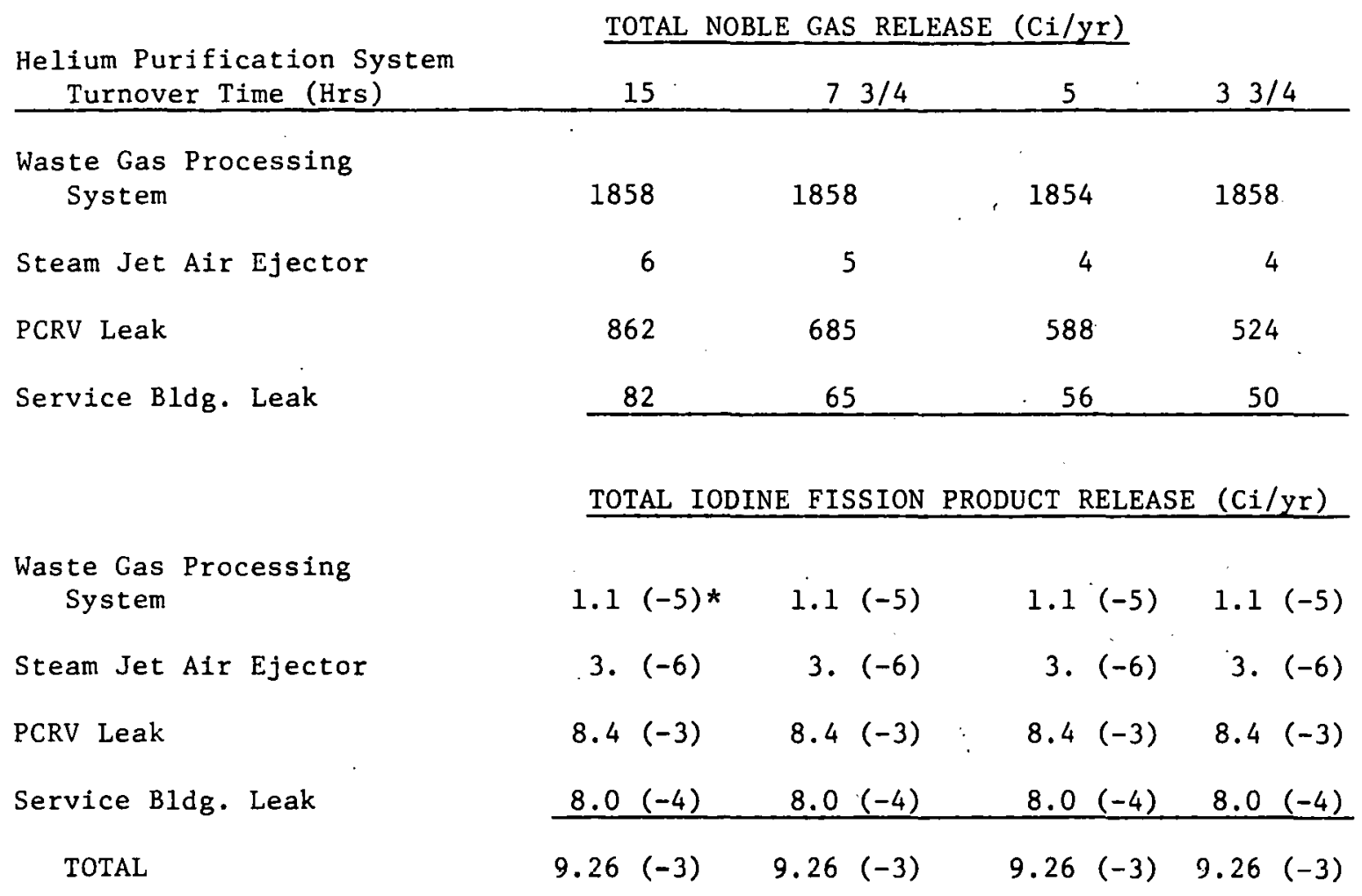

$\star 1.1(-5)=1.1 \times 10^{-5}$ 


\section{References}

1. C. J. Barton, R. E. Moore and S. R. Hanna, Radiation Doses from Hypothetical Exposures to Rulison Gas. Nuclear Technology 20. 35-50 (1973).

2. General Atomic, H1gh Temperature Nuclear Heat Source Study, USAEC Report GA-A113158, December 1974.

3. G. G. Killough and Larry R. McKay, Compilers, A Methodology for Calculating Radiation Doses from Radioactivity Released to the Environment, ORNL-4992, 'lable 3.4, March 1976.

\section{Tables}

5-1 Noble Gas and Iodine Fission Product Release, Purification System Turnover Time 15 Hours.

5-2 Noble Gas and Iodine Fission Product Release, Purification System Turnover Time 7 1/2 Hours.

5-3 Noble Gas and Iodine Fission Product Release, Purification System Turnover Time 5 Hours.

5-4 Noble Gas and Iodine Fission Product Release, Purification System Turnover Time $33 / 4$ Hours.

5-5 Systems Total Noble Gas and Iodine Fission Product Release vs Purification System Turnover Time. 
VI. TRITIUM RELEASE TO THE ENVIRONMENT

Hydrogen and its isotopes, deuterium and tritium, have the interesting property of being able to diffuse through most metals quite readily at high temperatures, with the rate of diffusion increasing with temperature. This poses the possibility of two problems for VHTRs used as sources of process heat; first, that of hydrogen diffusing from the product stream through the walls of the reformer into the primary coolant, and that of tritium diffusing in the reverse direction from the primary coolant through the walls of the reformer into the product stream. The rates of diffusion depend upon the metal, and are very sensitive to the presence of an oxide coating on the surface of the metal, being in some cases orders of magnitude less than that for the bare metal.

Tritium, the 12.26-yr. half-life isotope of hydrogen, is generally classified as a low-toxicity radiolsotope because of its low energy beta emissions $(0.0186 \mathrm{Mev})$. However, because it is chemically indistinguishable from hydrogen, it is desirable to limit the concentration of tritium in the product stream of a VHTR.

In a VHTR, tritium can be produced from impurities by neutron capture as follows: ${ }^{3}$
a. $\mathrm{He}-3(\mathrm{n}, \mathrm{p}) \mathrm{H}-3$,
$\sigma_{\text {eff }}=2800$ barns
b. Li-6 $(n, \alpha) H-3$,
$\sigma$ eff $=463$ barns
c. $B-10(n, \alpha)$ Li-7
$\sigma^{\sigma} 2200=4010$ barns
$\mathrm{Li}-7$ (n, a) $\mathrm{H}-3$
$\sigma$ eff $=0.153$ barns
d. $\mathrm{B}-10(\mathrm{n}, 2 \alpha) \mathrm{H}-3$
$\sigma_{\text {eff }}=0.050$ barns

The abundance of $\mathrm{He}-3$ in natural Helium (mainly He-4) varies, depending upon the source, and it is of the order of $0.2 \mathrm{ppm}$ for the helium used in the primary coolant. Lithium is a contaminant of the core graphite.

Boron is used in the control rods and as a burnable poison.

Tritium is also produced by ternary fission to the extent of 0.8 to $1.25 \times 10^{-4}$ atoms of tritium per fission. While this is the mode of 
largest production of tritium in a VHTR, it is expected that only about $0.55 \%$ of the tritium produced in the fuel will escape from the particles to the primary coolant.

Table 6-1 (part of Table 4 in Reference 3) summarizes the annual producttion rate of tritium and its release rate to the primary coolant of a 3000 MWt HTGR. Since, in this respect, the VHTR is similar to the HTGR, the results are applicable to the VHTR. It was assumed that the lithium impurity in the core and reflector graphite was $0.01 \mathrm{ppm}$, and that all of the tritium generated by the $\mathrm{He}-3, \mathrm{Li}-6$, and $\mathrm{B}-10$ activation reactions was ultimately released to the primary coolant.

Calculations by Compere 4 (see Appendix A) of the diffusion rate of tritium into the reformer and steam generator as a function of the helium purification system turnover time are summarized in Tables 6-2 and 6-3. Figure 6-1 is a plot of the data in Table 6-2, the fraction of primary coolant tritium diffusing through the reformer and the steam generator, and that removed by the helium purification system plotted against reciprocal helium purification system turnover time. From the figure it is apparent that the helium purification system removes $80 \%$ or more of the tritium when the system turnover time is 11 hours or less. The tritium and hydrogen removed by the helium purification system is ultimately processed as solid waste for off-sile dispusal.

Table 6-3 lists the steady state tritium activity in the primary coolant, the tritium diffusive flow thru the retormer and resulting concentration in the product stream, the diffusive flow through the steam generator, and the triclum removal rate in the helium purification system.* These are conservative values (upper limit) since the permeation coefficients used are for "bare" metal, and no allowance made for the effects of any "protective" oxide films that may be present (or develop) in the reformers or steam generators. If "protective" oxide films are present, then these values could be conservative by as much as an order of magnitude or so. The tritium concentration in the steam from the steam

* The calculations of tritium in the product are essentially the same as those reported in analogous studies by General Atomic.9, 10 
generator was not calculated because it is determined by the steam generator blowdown rate and the feed water purification system. Thus the steam generator blowdown is one pathway for release of tritium to the environment and the maximum annual release via this pathway is about $615 \mathrm{Ci}$.

Estimates of doses resulting from two possible usages of the product gas $\left(88 \% \mathrm{H}_{2}, 12 \% \mathrm{CH}_{4}\right)$ containing $0.1 \mathrm{pCi}$ of tritium per standard $\mathrm{cm}^{3}$ were made. The first case 5 assumes the tritiated hydrogen in the product gas is used to hydrogenate edible oils in the production of margarine. This situation was considered by Barton and Reynolds ${ }^{5}$ who assumed a tritium concentration of $0.5 \mathrm{pCi} / \mathrm{cm}^{3}$ and that the molecular weight of the hydrocarbon is 282 (oleic acid). The calculated concentration in this case is $0.018 \mu \mathrm{Ci} / \mathrm{lb}$ of product and the annual whole-body dose, assuming ingestion of $1 \mathrm{lb} /$ day of margarine, is 0.4 millirem. Ingestion of the tritiated margarine using $\mathrm{H}_{2}$ containing $0.1 \mathrm{pCi} / \mathrm{cm}^{3}$ and a more reasonable consumption rate of $0.1 \mathrm{lb} / \mathrm{day}$ would result in an annual whole-body dose of approximately $0.01 \mathrm{mrem} /$ year. This dose is about $0.01 \%$ of that resulting from natural background radiation.

In the second case ${ }^{6}$ it was assumed (as in Section V) that a 50-50 mix of the tritiated hydrogen product gas and natural gas was burned in an unvented kitchen range, the situation considered earlier by Barton, et. al. The resulting whole-body dose to occupants of the house was calculated to be 0.006 millirem/ year. This dose is the same order of magnitude as in the first case.

Individual and population doses from use of ail the product gas $\left(822 \times 10^{6} \mathrm{ft}^{3} /\right.$ day) as a $50 / 50$ mixture with natural gas can be estimated by comparison with results of an earlier study ${ }^{7}$ of doses from use of tritiated natural gas in the Los Angeles Basin, one of the few 
metropolitan areas in this country that can consume quantities of natural gas of this magnitude. In that investigation it was assumed that the gas consumed in the basin contained $1 \mathrm{pCi}$ of tritium per $\mathrm{cm}^{3}$ giving an estimated weighted average dose of $0.47 \mathrm{millirem} /$ year. Making the further assumption that the total quantity of gas used in metropolitan Ins Angelps is equal to the output of the process heat plant, after dilution with an equal volume of natural gas, and that this is equal to the volume used in making the earlier dose calculation, 7 the average individual dose becomes $0.024 \mathrm{millirem} /$ year and the population dose to the approxi.mately 7 million people residing in this area is $168 \mathrm{man}-\mathrm{rem} / \mathrm{year}$. The average individual dose of $0.47 \mathrm{millirem} /$ year was estimated on the assumption that $10 \%$ of the homes had unvented gas heaters, an unduly pessimistic assumption because, as was pointed out in another publication, ${ }^{6}$ this practice is illegal in most places. Also, home appliances other than the kitchen range are almost invariably vented. The low home dilution factor of 170 used in another report ${ }^{8}$ required the assumption that all gas appliances as well as the gas heater are unvented. The dilution factor of 7540 reported earlier ${ }^{7}$ and used in this report assumed that only the kitchen range is unvented. 
TABLE 6-1

TRITIUM ANNUAL PRODUCTION AND RELEASE TO PRIMARY COOLANT OF A 3000 MWt VHTR

Source

Ternery Fission

He-3 Activation

Li-6 Activation Core Graphite Core Matrix Reflector (temporary) Reflector (permanent)

B-10 Activation

Control Rod

Burnable Poison

Reflector

TOTAL

\section{PRODUCTION \\ (Ci/yr)}

10,000

3,290

310

1,809

62

40

1,100

208

3

16,822
RELEASE TO

PRIMARY COOLANT

( $\mathrm{Ci} / \mathrm{yr}$ )

55

3,290

310

1,809

62

40

1,100

208

3

6,877 
TABLE 6-2

FRACTION OF PRIMARY COOLANT TRITIUM DIFFUSING

THRU THE REFORMER, STEAM GENERATOR, AND REMOVED BY

THE HELIUM PURIFICATION SYSTEM VS HELIUM PURIFICATION SYSTEM TURNOVER TIME

FRACTION OF PRIMARY COOLANT TRITIUM

$\begin{array}{cccc}\begin{array}{c}\text { Turnover } \\ \text { Time } \\ \text { (Hours) }\end{array} & \text { Reformer } & \begin{array}{c}\text { Steam } \\ \text { Generator }\end{array} & \begin{array}{c}\text { He-Purification } \\ \text { System }\end{array} \\ 3.75 & 0.072 & 0.046 & 0.882 \\ 5.00 & 0.083 & 0.053 & 0.864 \\ 7.50 & 0.100 & 0.064 & 0.836 \\ 15.00 & 0.139 & 0.089 & 0.772 \\ \infty & 0.611 & 0.889 & 0.000\end{array}$


TABLE $6-3$

TRITIUM CONCENTRATION AND FLOW RATES

VS

HELIUM PURIFICATION SYSTEM TURNOVER TIME

\begin{tabular}{|c|c|c|c|c|c|c|}
\hline \multirow[b]{2}{*}{$\begin{array}{c}\text { Turnover } \\
\text { Time }\end{array}$} & \multicolumn{2}{|c|}{ Primary Coolant } & \multicolumn{2}{|c|}{ Reformer } & \multirow{2}{*}{$\begin{array}{c}\text { Steam } \\
\text { Generator } \\
\text { Flow }\end{array}$} & \multirow{2}{*}{$\begin{array}{l}\text { Helium } \\
\text { Pur. Syst. } \\
\text { Removal } \\
\text { Rate }\end{array}$} \\
\hline & Activity & Concentration & Flow & $\begin{array}{l}\text { Conc. } \\
\text { In Product }\end{array}$ & & \\
\hline Hours & CI & $\mathrm{pCi} /$ Std $\mathrm{CC}$ & $\mathrm{Ci} / \mathrm{hr}$ & $\mathrm{pCi} / \mathrm{Std} \cdot \mathrm{CC}$ & $\mathrm{Ci} / \mathrm{hr}$ & $\mathrm{Ci} / \mathrm{hr}$ \\
\hline 3.75 & 3.78 & 66.3 & 0.0821 & 0.0801 & 0.0525 & 1.006 \\
\hline 5.00 & 4.93 & 86.7 & 0.0947 & 0.0920 & 0.0605 & 0.986 \\
\hline 7.50 & 7.15 & 126. & 0.114 & 0.112 & 0.0730 & 0.954 \\
\hline 15.00 & 13.2 & 232 . & 0.159 & 0.155 & 0.102 & 0.881 \\
\hline$\infty$ & & & 0.697 & 0.681 & 0.444 & 0.000 \\
\hline
\end{tabular}

(a) For an Annual Flow of $10,000 \mathrm{Ci}$. of Tritium to the Primary Coolant 


\section{TABLE 6-4}

HYDROGEN PERMEATION RATES THRU REFORMER AND STEAM GENERATOR AND REMOVAL RATE FROM PRIMARY COOLANT BY HELIUM PURIFICATION SYSTEM

He-Pur. Syst. Turnover

Hydrogen Pcrmcation

Rate thru Reformer to primary

Coolant (Moles/hr)

166.2

166.2166 .2166 .2

166.2

Back Flow from Primary

Coolant thru Reformer

(Moles/hr)

18.5

21.0

$25.1 \quad 33.4$

101.6

Net $\mathrm{H}_{2}$ Flow to Primary

Coolant (Moles/hr)

147.7

$\begin{array}{lll}145.2 & 141.2 & 132.8\end{array}$

64.6

$\mathrm{H}_{2}$ Flow thru Steam

Generators (Moles/hr)

11.8

13.4

16.0

21.3

64.6

$\mathrm{H}_{2}$ Flow to Helium Purffication

Bystein (Móles/hi)

135.9

131.8

$125.1 \quad 111.5$

0.0

$\mathrm{H}_{2}$ Partial Pressure in Primary

Coolant (at mos.)

0.0097

0.0125

0.01790 .0318

$0.29 \dot{3}$

$\mathrm{H}_{2}$ ppm in Primary Coolant (ppm)

205.

264 .

378.

671

6180

(a) Avg. Primary Coolant Pressure $=697$ psia $=47.4$ amos.

(b) Permeation coefficients assumed for "clean" or bare metal 


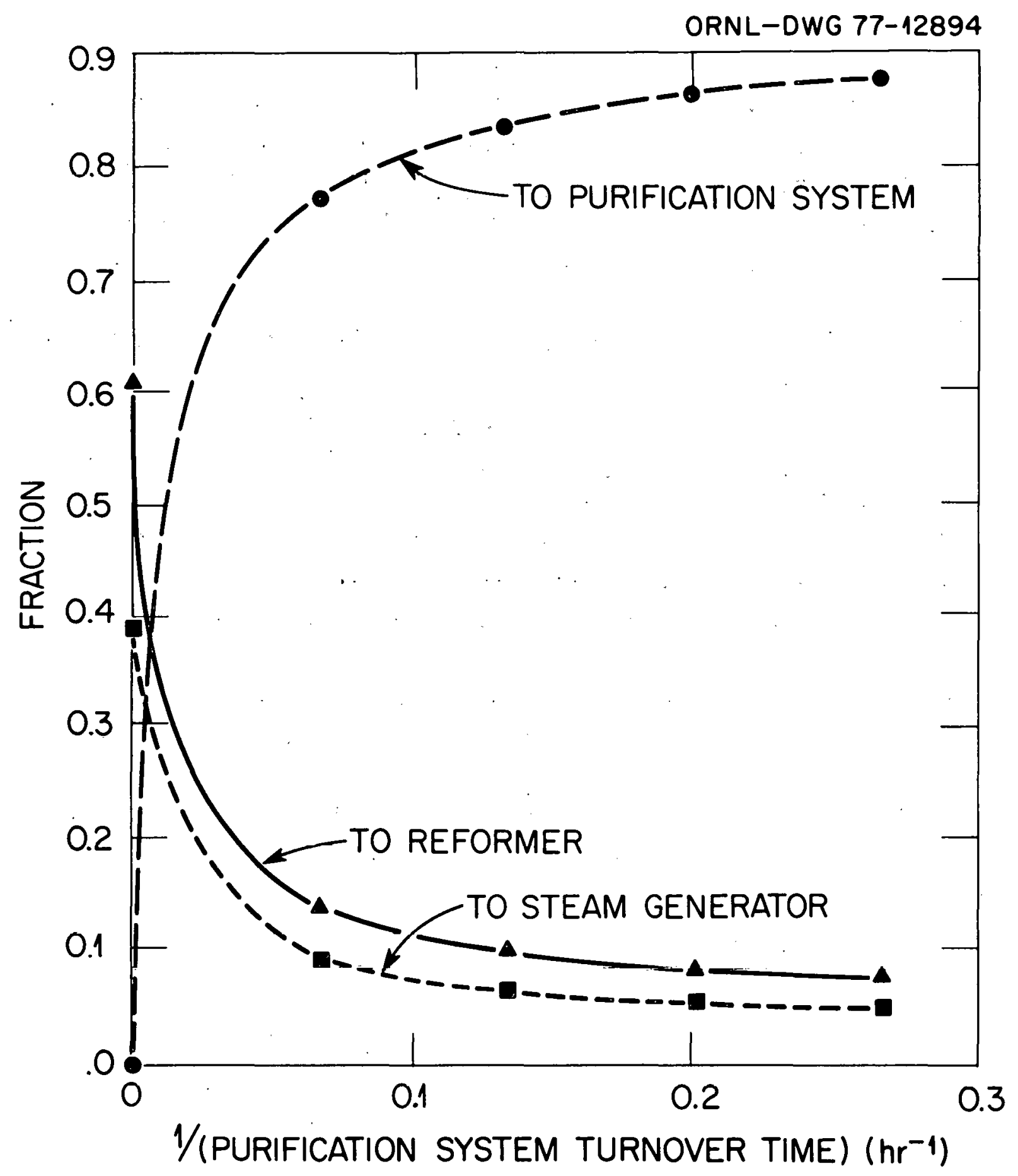

Fig. 6-1. Fraction Primary Coolant Tritium to Purification System; Reformer; and Steam Generator; vs $1 /$ (Purification System Turnover Time) $\mathrm{Hrs}^{-1}$ 


\section{References}

1. R. A. Strehlow and H. C. Savage, "The Permeation of Hydrogen Isotopes through Structural Metals at Low Pressures and Through Metals with Oxide Film Barriers", Nuclear Technology, Vo1. 22, April 1974.

2. R. A. Strehlow and H. C. Savage, "Formation and Use of Oxide Films to Impede Outgassing of Metals", Journal of Nuclear Materials, Vol. 53, Sept. 1974.

3. B. W. Gainey, A Review of Tritium Behavior in HTGR Systems, GA-A13461, General Atomics Co., April 1976.

4. E. L. Compere, Transport of Tritium from VHTR Coolant into SteamMethane Reformer Product Hydrogen, ORNL Intra-Laboratory Correspondence, July 1, 1976.

5. C. J. Barton and S. A. Reynolds, "Estimated Radiation Doses from Ingestion of Tritium-Containing Consumer Products Made with Hydrocarbons from Nuclearly Stimulated Natural Gas Wells", ORNL-TM-4730, December, 1974.

6. C. J. Barton, R. E. Moore and S. R. Hanna, "Radiation Doses from Hypothetical Exposures to Rulison Gas", Nuclear Technology, Vol. 20, 35-50 (1973).

7. D. G. Jacobs et al., "Consideration of the Radiological Impact from the Hypothetical Use of Contaminated Natural Gas from Nuclearly Stimulated Reservoirs", Health Physics, Vol. 22, 429-440 (1972).

8. Project Staff, General Atomic, "Process Heat Engineering Design Studies for Very High Temperature Reactors", GA-A13801, Section 10.4.1.5, July 1976.

9. Ibid, P. 10-25.

10. Project Staff, General Atomic, "Further Process Heat Engineering Design Studies for Very-High-Temperature Reactors", GA-A14103, November, 1976, p. $6-10$. 
Tables

6-1. Tritium Annual Production and Release to Primary Coolant of a 3000 MWt VHTR (from Table 4, GA-A13461).

6-2. Fraction of Primary Coolant Tritium Diffusing Thru the Reformer and Thru the Steam Generator, and Removed by the Helium Purification System vs Helium Purification System Turnover Time.

6-3. Tritium Concentration and Flow Rates vs Helium Purification System Turnover Time.

6-4. Hydrogen Permeation Rates Thru Reformer and Steam Generator, and Removal Rate from Primary Coolant by Helium Purification System.

\section{Figures}

6-1. Fraction Primary Coolant Tritium to Purification System, Reformer, and Steam Generator vs Reciprocal Purification System Turnover Time. 


\section{SAFETY CONSIDERATIONS}

The previous sections have considered the release of radionuclides into the environment as a consequence of normal operation of a VHTR to provide process heat via steam-methane reforming. The results indicate that, even without an IHX, individual annual doses from such releases are very low compared to those from natural background radiation. (Based on currently active cost-benefit considerations for LWRs and the calculated cumulative annual population dose, there mạ be some incentive for further reduction of the release rates.) However, the safety characteristics of a given system must also be considered in an overall examination of the suitability of that system for a particular application. Any substantive discussion of specific safety features would require detailed analysis of a specific, detailed system design - which is beyond the scope of this work. The purpose of this section is to identify those safety features of VHTRs that relate to the need (or lack thereof) for the IHX and should, therefore, be considered along with the normal environmental effects in assessing this need.

The VHTR under consideration (without IHX) is very similar to the steam-cycle HTGR developed by the General Atomic Company with the following differences in the case of the VHTR:

a. The primary coolant temperature at the reartor nutlet is $2110^{\circ} \mathrm{K}$. higher than for the HTGR. Hence the maximum coolant temperature (liot cliamel vullel) is expected to be about $110^{n} \mathrm{~K}$ greater than for the HTGR.

b. The average fuel temperature is $235^{\circ} \mathrm{K}$ higher and the maximum fuel tcmperature is $53^{\circ} \mathrm{K}$ lower than for the HTGR (due to changes in luel-bluck deslgn).

c. The average and maximum moderator temperatures are $\sim 100^{\circ}$ and $103^{\circ} \mathrm{K}$ higher. 
d. The steam-methane reformers (process heat application) are installed in the PCRV with only one barrier between the primary coolant and the process fluid.

e. Less steam generator capacity is required.

A significantly different list results if the IHX concept is considered. The most prominent change, of course, would be the almost complete isolation of the reactor primary circuit from the steam generators and steam-methane reformers. Other changes would be associated with the values of temperature shifts from the nominal HTGR. If the same process temperature were required in the IHX system, all of the primary circuit temperatures would be raised by another $50^{\circ}$ to $100^{\circ} \mathrm{K}$. Conversely, if the same maximum temperatures were maintained in the primary circuit, there would be a considerable shift in plant performance (principally because of lower temperatures in the reformers). The optimum conditions for a system with IHX cannot be defined without a major design study in which the "costs" associated with higher primary temperatures are balanced against the "costs" of poorer process performances.

Design of an HTGR to much higher temperatures could require major changes in system layout and specification of different core structural materials to retain satisfactory margins between operating temperatures and material damage temperatures. (All materials other than graphite could be affected.) Such changes could, in principle alter the safety characteristics of the system. It is presumed that a modified, highertemperature system would be selected only if safety margins were shown to be as satisfactory as those of lower temperature systems. Thus it is unlikely that the order of importance of safety-significant events would change markedly, solely because of changes in primary-system temperatures. Therefore, safety-associated events that lead only to temperature increases in the primary circuit provide no basis for choosing between a process heat reactor with IHX and one without IHX. 
Based on the above discussion, it appears that the design-basis accident for the process heat VHTR would, as for the HTGR, be the depressurization of the primary circuit. System temperatures and other conditions reached during the Design Basis Depressurization Accident (DBDA) would be different for the VHTR (either with or without IHX), than for the HTGR. These conditions would have to be factored into the design of the VHTR, but it seems unlikely that the basic conclusions regarding the DBDA would be changed.

Events that involve the intermixing of various fluids appear to offer the greatest potential for changes frnm the safety and safety-rolatod behavior of the "normal" HTGR. Among the processes that would have to be analyzed in detall for the VHTR concept are the following:

Chronic, low-rate water ingress to primary circuit.

Steam-generator failures which lead to rapid water ingress to primary circuit.

Steam system failures into containment.

Chronic hydrogen ingress to primary circuit from the reformers.

Reformer failures into primary circuit.

Reformer system failures into containment.

In general, these events are applicable only to the close-coupled concept without IHX.

Because of the higher graphite temperatures in the VHTR, the consequences of graphite corrosion due to chronic, low-rate steam (water) ingress could conceivably be more severe than in the HGTR. ${ }^{1,2}$ While the absolute rate of water ingress may be lower for the VHTR (smaller steam generators, hence fewer tubes, welds, etc. to leak), the strong dependence of the steam-carbon reaction on temperature could lead to enhanced, localized attack. A potential location for such enhanced attack Is the graphite core-support posts; ${ }^{2}$. this could (in the absence of design adjustments to compensate for the corrosion) lead to reduced safety margins. 
However, a comprehensive and detailed analysis would be required to identify any undesirable effects of low-rate steam corrosion in a given VHTR configuration. It currently appears that any such effects could be accommodated by reasonable adjustments in system design without degrading the overall system safety.

A steam-generator failure that leads to a major water-ingress event may be more difficult to assess. Locally high temperatures in the VHTR, when combined with the potential for nonuniform distribution of steam (water) from a large leak, could lead to large corrosion effects in local areas. It likely would be difficult to demonstrate analytically that all such combinations would have acceptable consequences.

Leaks from the steam system into the reactor containment would be no different for a VHTR than for any other HTGR. Since the consequences of this event are generally not serious for the HTGR, ${ }^{3}$ this type of failure offers little incentive for using IHXs.

The presence of high concentrations (or partial pressures) of elemental hydrogen on the process side of the reformers would lead to substantial diffusion of hydrogen directly into the primary coolant if IHXs are not used. While much of this hydrogen would be removed by the primary-coolant purification system, a significant amount would be available to interact with other primary circuit materials. Among the possible interactions to be considered are:

1. effects on the rate of the steam-carbon reaction;

2. direct corrosion of graphite by hydrogen, resulting in carbon removal and mass transfer to other regions;

3. indirect effects of carbon mass transfer, such as alteration of flssion-product deposition and liftoff behavior or metal carburization;

4. hydrogen embrittlement of metallic components in the primary circult. 
With direct heating of the reformer by primary coolant, any tube (or header) failure in the reformer would produce a partial "depressurization accident" in the primary circuit as reactor coolant flowed to the lower-pressure process system. Detailed analysis would be required to demonstrate that all such events are within the envelope of accidents defined by the DBDA. Another direct effect of such reformer failures would be contamination of the product gas with extra radioactive material. If such contamination were significant, the contaminated product would have to be quickly diverted to a disposal or cleanup system to prevent distribution of the extra activity.

Recent studies suggest that the process gas released as a consequence of a reformer-system failure to containment could produce a combustible mixture in the containment. ${ }^{4}$ Elimination of this possibility would require either an inert atmosphere within the containment or elimination of all credible mechanisms for releasing process gas into the containment. The latter approach appears to require the use of IHXs or highly specialized and reliable designs for selected parts of the reformer system.

This preliminary review of some of the safety considerations associated with the use of VHTRs in process heat applications indicates that reactor safety will play a major, if not dominant, role in defining acceptable system configurations for such applications. The safety information that has been developed to date for this particular process heat concept does not provide a clear basis for either requiring or eliminating $1 \mathrm{HXs}$. It does indicate, instead, that a reasonably detailed safety analysis will likely be required for each specific configuration that is considered before a final choice is made. 


\section{References}

1. A. W. Barsell and M. B. Peroomian, Consequences of Water Ingress Into the HTGR Primary Coolant, GA-A13171, General Atomics Co., April 15, 1975.

2. R. P. Wichner, Effect of Steam Corrosion on Core Post Strength Loss: Case of Low, Chronic Steam Ingress Rates, ORNL-TM-5534, Oak Ridge National Laboratory, In Press.

3. Fulton Generating Stations 1 and 2 Preliminary Safety Analysis Report, p. 15.3-8.

4. Process Heat Engineering Design Studies for Very High Temperature Reactors, GA-A13801, General Atomic Co., July 1976; p. 10-4. 
VIII. IS THE INTERMEDIATE HEAT EXCHANGER (IHX) NECESSARY?

The primary contribution to contamination of product gas in the case studied is from tritium activity. Calculations incorporating several modes of gas usage, Chapter VI, indicate that a 168 man-rem/year dose could be expected in metropolitan Los Angeles. This same area receives a population dose of 910,000 man-rem/year from natural radiation sources, if we assume that the U. S. average of $130 \mathrm{millirem} /$ year applies. ${ }^{1}$

Using the guidelines established in 10 CFR 50 which consider each man-rem that the population dose can be reduced worth $\$ 1000$, the sum of $\$ 168,000 /$ year would be established for equipment -- such as IHX -- to reduce the calculated dose to users. Assuming a plant lifetime of approximately 30 years and an interest rate of $10 \%$ gives a present worth value of $\$ 1.5 \times 10^{6}$. This is the present day investment that can be made to eliminate the $168 \mathrm{man}-\mathrm{rem} /$ year population dose for the lifetime of the plant, which translates to the amount of expenditure that could reasonably be considered for the IHX capital cost plus operating and maintenance costs for an equivalent 30 year period.

Estimates have been made of the cost of constructing and operating an IHX. ${ }^{2}$ The installed capital cost of the IHX is given as $\$ 41 \times 10^{6}$ (January 1976). Consideration of this capital cost figure alone, without including the operating and maintenance cost, gives a cost/benefit ratio of $41 / 1.5=26$.

Therefore, it appears that the construction of an IHX for reduction of man-rem exposures predicted is not justified.

It appears that the long-term steam corrosion of the core support posts necessitates increasing their diameter. However, the hydrogen contaminant in the primary coolant, which permeates the reformer, may reduce the steam corrosion, but it may produce other problems which have not as yet been resolved. An IHX in parallel with both the reformer and the 
steam generator would alleviate these problems, but probably at greater cost than that of increasing the size of the core support posts. It is recommended that the corrosion problem be examined in more detail, especially by investigating the performance of current fossil fuel heated reformers in industry.

Detailed safety analysis of the VHTR would be required to establish definitively whether the IHX can be eliminated. Water and hydrogen ingress into the reactor system are potential problems which can be alleviated by an IHX. The problems will require analysis, research and development within the program required for development of the VHTR. 


\section{References}

1. Estimates of Ionizing Radiation Doses in the United States, U.S. Environmental Protection Agency, ORP/CSD 72-1, August 1972.

2. Process Heat Engineering Design Studies for Very-High Temperature Reactors, GA-A13801, General Atomic Project 3231, July 1976. 
APPENDIX A

TRANSPORT OF TRITIUM FROM VHTR COOLANT INTO

STEAM-METHANE REFORMER PRODUCT HYDROGEN

E. L. Compere

The transfer of reactor tritium to product streams in a VHTR supplying process heat for the steam reforming of methane is estimated below. The model HTGR for Hydrogen Production, described ${ }^{3}$ in GA-A13391 does not use an intermediate heat exchanger, but in order to obtain maximum process temperatures, passes the reactor primary coolant gas directly over the reformer tubes. Additional energy is extracted from the primary coolant by a steam generator prior to return of the gas to the reactor core. As in other HTGRs, a small fraction of the gas is diverted to a coolant purification system, which effectively removes the various impurities, including $\mathrm{H}_{2} \mathrm{O}, \mathrm{H}_{2}, \mathrm{CH}_{4}, \mathrm{CO}, \mathrm{CO}_{2}$ and other species from it.

Tritium formed by ternary fission may escape from failed fuel particles, or more slowly from intact particles. It is additionally formed from lithium and other impurities in graphite, from boroncontaining control materials, and from traces of ${ }^{3} \mathrm{He}$ in natural helium. This and the tritium not retained by fuel particles may be expected to enter the primary coolant gas. The possibility of tritium and hydrogen interaction with reactor graphite is recognized, this is not taken into account in the steady state solutions considered below. This is appropriate for a conservative limit calculation, since any interaction with graphite would serve as "sink", reducing the fraction of tritium transferred elsewhere. The rate and extent of tritium interaction with graphite is not established, but it is not expected to be a major effect relative to transport considered here.

It is assumed that tritium entering the primary coolant gas is removed ( 1 ) by permeation into the reformer, thus entering the product gas stream, (2) by permeation into the steam generator, and (3) by passage into the coolant purification system. After tritium has entered the 
reformer gas it will doubtless be distributed among the various species there. The streams emerging from the plant are essentially only the product hydrogen and byproduct carbon dioxide streams. Internally recycled streams will thereby in time reach a steady concentration of tritium, and both hydrogen and tritium can be regarded as passing directly through. The decay of tritium is conservatively ignored in the present calculation. Thus the present calculation evaluates the fractional distribution of source tritium entering the primary conlant to the respective sinks, under steady state conditions. The amounts thus indicated to enter the product stream should be conservative upper limits.

Tritium entering the primary coolant becomes immediately mingled with a much larger quantity of "natural" hydrogen (largely ${ }^{1_{H_{2}}}$ ) which enters by permeation from the reformer, and which is removed along with the tritium (which is largely ${ }^{1} \mathrm{H}{ }^{3}$ or "HT"). In order to estimate the fraction of primary coolant tritium entering the various "sinks", in particular the reformer, it is first necessary to characterize the behavior of natural hydrogen in the system and from this to evaluate the behavior of tritium,

The permeation of hydrogen through metals in the absence of oxide films is proportional to the product of its solubility in the metal, and the diffusion parameters of the hydrogen atoms through the metal. The solubility follows Sievert's law, in which solubility is proportional to the square root of hydrogen pressure. An appreclable dependence on temperature is involved. The dependence of diffusion on temperature is relatively minor, consequently the permeation coefficient, which is the product of solubility and diffusion coefficients, will be determined by the temperature at which the gas enters the metal. Downstream hydrogen pressures will be regarded as resulting in a concurrent reverse transport, to be handled separately. 
German studies ${ }^{5}$ consistent with the findings of Strehlow and Savage, have shown that oxidation of reformer metals could lower hydrogen and tritium permeation rates considerably. However, since the maximum rate of tritium transport into the reformer gas is sought here, the reformer metal will be regarded as unoxidized. The effect of oxide films on the hydrogen permeation of steam generator metals may be similar ${ }^{2}$, but the sustained effect of films anticipated to occur only on the water side is uncertain. The permeation coefficient used is that of unoxidized metal, resulting in the maximum of possible rates by this path also. Such a parameter can be set to zero, simulating an impermeable film if desired. Meaningful intermediate values are not avallable.

In the reformer, the partial pressure of hydrogen and the temperature vary appreciably along the length of a reformer tube. In our calculation we assume a linear variation of both temperature and pressure along the length, divide the tube into a number of sections, and assign an average surface temperature and hydrogen pressure to each section. On the reactor gas side, similarly the temperature variation is taken into account. The gas is circulated rapidly, however, with minor pressure drop, so that the partial pressure of hydrogen can be regarded as constant around the circuit.

The available documentation did not characterize the steam generators adequately. However, to a predominant extent the characteristics for various sizes will be similar except for area, so that hydrogen permeation at given partial pressures can be scaled directly to power removal. The basis of the coefficient used was that evaluated for steam generators similar to the Fort Saint Vrain HTGR (See Reference 1). A further evaluation of the steam generator coefficient could be made using additional information about the proposed equipment. 
The equations relating hydrogen transfer (in moles/hr) to and from the primary circuit are given below:

From Reformer:

(1) $\quad Q_{0}=\sum \frac{A_{i} K_{i} P_{i}^{1 / 2}}{1_{i}}$

To Reformer:

(2)

$$
Q_{1}=\left(\sum \frac{A_{i} K_{i}^{*}}{1_{i}}\right) \cdot \pi^{1 / 2}
$$

To Steam Generator:

(3) $\mathrm{Q}_{2}=\left(\frac{\text { Transfer rate }}{\mathrm{MW} \cdot \pi^{1 / 2}}\right)_{\text {FSVR }} \cdot \mathrm{MW} \cdot \pi^{1 / 2}$

To Purification:

(4) $Q_{3}=\quad r_{\text {pur }} \cdot\left(\frac{\text { moles He inventory }}{\text { atm He inventory }}\right)=\pi$

Where:

$A_{i}=$ area of reformer tube segment $(i),\left(\right.$ al1 tubes) $\mathrm{cm}^{2}$

$\mathrm{K}_{i}$ = permeation coefficient of hydrogen through reformer tube

at segment $i$, based on surface temperature on reformer side,

$\frac{\text { moles } \mathrm{cm}}{\mathrm{hr} \mathrm{cm}^{2} \text { at } \mathrm{m}^{1 / 2}}$ 


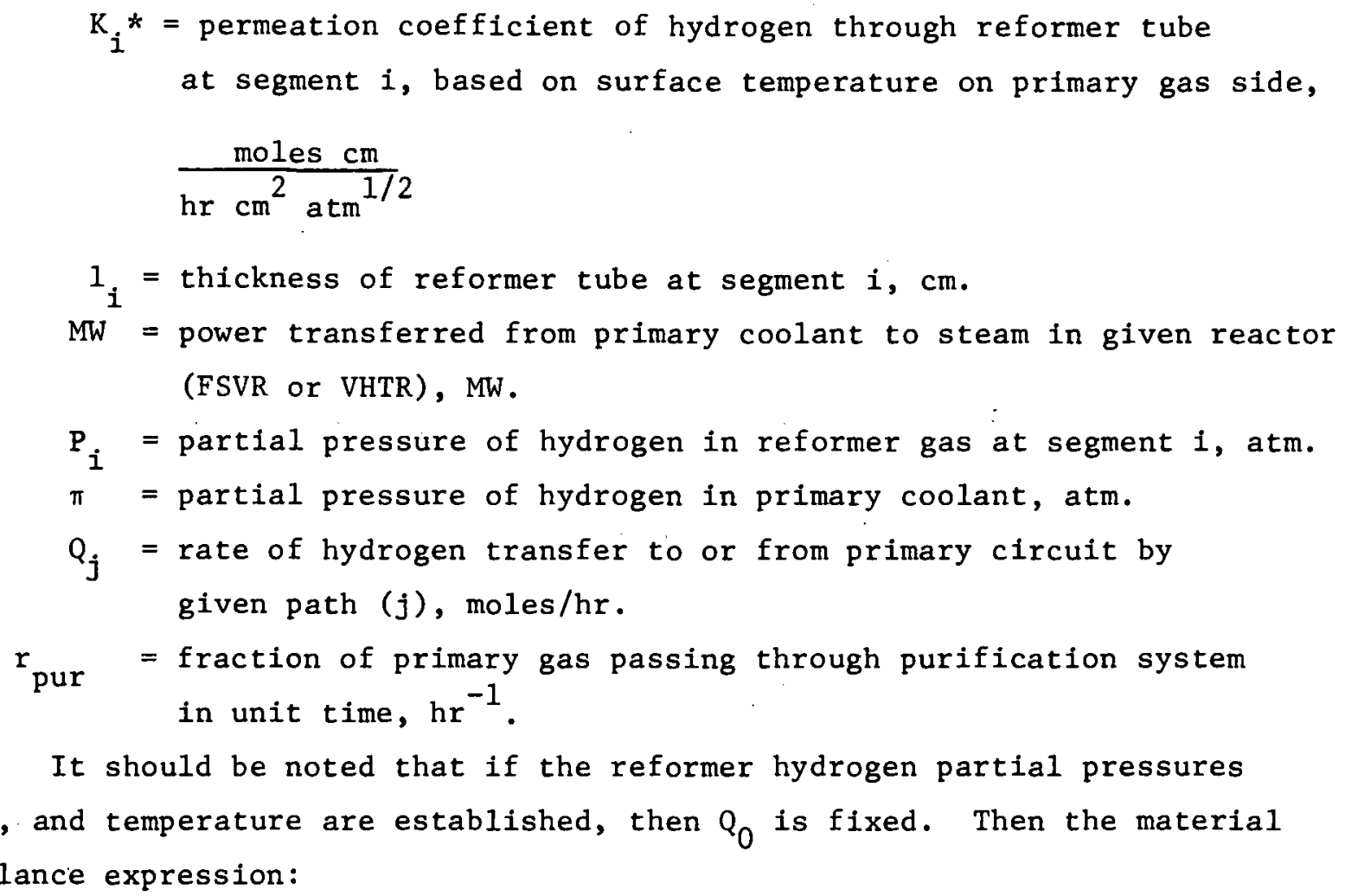

(5) $Q_{0}=Q_{1}+Q_{2}+Q_{3}$

is a quadratic equation in $\pi^{1 / 2}$, and may be solved by formula. With the value of $\pi$ thus available the values of $Q_{1}, Q_{2}$, and $Q_{3}$ may be evaluated.

The distribution of tritium follows that of hydrogen except that permeation of tritium is somewhat slower; a literature factor of 0.6 is used.

The rate of transfer of tritium is then given as follows:

(6) $R_{0}=$ Source rate to primary gas

(7) $\mathrm{R}_{1}=\mathrm{F}_{1} \mathrm{R}_{0}=.6 \mathrm{Q}_{1} \cdot \frac{\pi_{\mathrm{HT}}}{\pi_{\mathrm{H}_{2}}}$

(8) $\mathrm{R}_{2}=\mathrm{F}_{2} \mathrm{R}_{0}=.6 \mathrm{Q}_{2} \cdot \frac{\pi_{\mathrm{HT}}}{\pi_{\mathrm{H}_{2}}}$ 
(9) $\mathrm{R}_{3}=\mathrm{F}_{3} \mathrm{R}_{0}=\mathrm{Q}_{3} \cdot \frac{{ }_{\mathrm{HT}}}{\pi_{\mathrm{H}}}$

and $\mathrm{R}_{0}=\mathrm{R}_{1}+\mathrm{R}_{2}+\mathrm{R}_{3}$

Where

$\mathrm{F}_{j}$ is the fraction of primary coolant tritium distributed along a particular path $j$.

$R_{j}$ is the amount of tritium transferred in unit time along a particular pāth, j.

Then the fractional distribution at steady state is:

To Reformer:

(10) $F_{1}=.6 Q_{1} /\left(.6 Q_{1}+.6 Q_{2}+Q_{3}\right)$

To Steam generator:

(11) $\mathrm{F}_{2}=.6 \mathrm{Q}_{2} /\left(.6 \mathrm{Q}_{1}+.6 \mathrm{Q}_{2}+\mathrm{Q}_{3}\right)$

To Purification system:

(12) $\mathrm{F}_{3}=\mathrm{Q}_{3} /\left(.6 \mathrm{Q}_{1}+.6 \mathrm{Q}_{2}+\mathrm{Q}_{3}\right)$

The computer program VHTR was written to facilitate the above calculaliun.

As a base case the following parameters were used:

Reformer inlet temperature $838^{\circ} \mathrm{K}$

Reformer exit temperature $1033^{\circ} \mathrm{K}$

Primary coolant temperature reformer inlet $933^{\circ} \mathrm{K}$

Primary coolant temperature at reformer exit 
Reformer hydrogen pressure at inlet

$1.06 \mathrm{~atm}$

Reformer hydrogen pressure at exit

$7.19 \mathrm{~atm}$

Reformer tubes, total area

$2.28 \times 10^{8} \mathrm{~cm}$

Reformer tube thickness

$1.27 \mathrm{~cm}$

Steam generator power

$1500 \mathrm{MW}$

Purification rate

$.2 \mathrm{hr}^{-1}$

Helium in primary circuit

$2.54 \times 10^{6} \mathrm{~g}$ moles

Reformer tube hydrogen permeation coefficient: ${ }^{4}$

$$
K, K^{*}=.00506 e^{-17700 / R T}
$$$$
\frac{\text { mole } \mathrm{cm}}{\mathrm{hr} \mathrm{cm}^{2} \mathrm{~atm}^{1 / 2}}
$$

Steam generator coefficient,

$$
\left[\frac{\text { moles } \mathrm{H}_{2} / \mathrm{hr}}{\mathrm{MW} \cdot \mathrm{atm}^{1 / 2}}\right]_{\text {FSVR }}=.06869
$$

On the basis of the above parameters the hydrogen partial pressure in the primary system was estimated as .01269 atm.

$$
\begin{array}{lll}
\text { Tritium fraction to reformer: } & \mathrm{F}_{1}=.0828 \\
& \text { to steam generator: } & \mathrm{F}_{2}=.0455 \\
& \text { to purification: } & \mathrm{F}_{3}=.8717
\end{array}
$$

As an example of the application of the above: An approximate upper limit on the rate of entry of tritium into the primary coolant of a 3000 MWt HTGR (i.e., the source term) is about $10^{4} \mathrm{Ci} / \mathrm{yr}$, (Gainey) or $.00032 \mathrm{C} 1 / \mathrm{sec}$.

The basis VHTR is estimated to produce $11.2 \mathrm{~kg}$. mole $\mathrm{H}_{2} / \mathrm{sec}$, $\left(2.50 \times 10^{8} \mathrm{std} \mathrm{cc} / \mathrm{sec}\right)$.

Thus the tritium concentration of the product is

$$
\frac{.00032 \times .0828}{2.50 \times 10^{8}}=1.06 \times 10^{-13} \mathrm{Ci} / \mathrm{std} \mathrm{cc} \mathrm{H} 2
$$


or

$.106 \times 10^{-6} \mu \mathrm{Ci} / \mathrm{std} \mathrm{cc} \mathrm{H}_{2}$

The MPC for HTO in air is .2 $210^{-6} \mu \mathrm{Ci} / \mathrm{ml}$ and for $\mathrm{HT}$ is about 400 times greater.

Thus it is not indicated that the product gas will contain intolerable concentration of tritium.

The effects of incorporation of such product hydrogen into consumer products may be considered separately. The models and parameters used in the above estimates are conservative but otherwise in good accord with established literature.

The computer program described above has been made available in order that the effects of other parameter values can be examined as desired. 


\section{References}

1. E. L. Compere, S. H. Freid, C. W. Nestor, Distribution and Release of Tritium in High Temperature Gas-Cooled Reactors as a Function of Design, Operational and Material Parameters, ORNL-TM-4303 (June 1974).

2. B. W. Gainey, A Review of Tritium Behavior in HTGR Systems, GA-A13461, (Apri1, 1976).

3. D. D. Peterman, R. W. Fontaine, R. N. Quade, L. V. Halver, A. M. Taharomis, Studies of the Use of High Temperature Nuclear Heat from an HTGR for Hydrogen Production, GA-A13391, (draft, Sept. 1975).

4. R. A. Strehlow and H. C. Savage, "The Permeation of Hydrogen Isotopes Through Structural Metals at Low Pressures and Through Metals with Oxide Film Barriers." Nuclear Technology, 22, 127-137 (1974).

5. H. D. Rohrig, R. Hecker, J. Blumensalt, J. Schaefer, "Studies on the Permeation of Hydrogen and Tritium in Nuclear Process Heat Installation", Nucl. Eng. and Design, 34, 157-167, (1975). 
THIS PAGE

\section{WAS INTENTIONALLY \\ LEFT BLANK}

$z^{i}$

$i$ 
ORNL/TM-5914

INTERNAL DISTRIBUTION

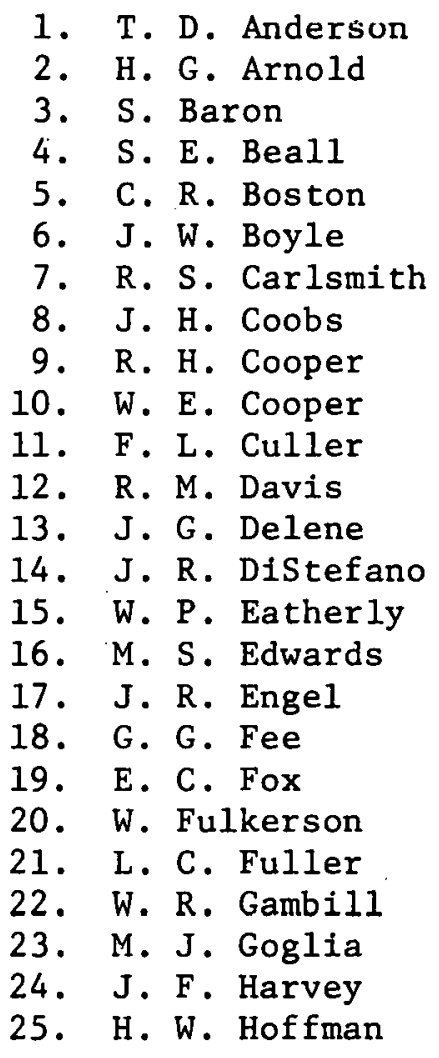

26. F. J. Homan

27. J. E. Jones, Jr.

28. P. R. Kasten

29. 0. H. Klepper

30. M. Levenson

31. C. C. Littlefield

32. R. E. MacPherson

33. A. P. Malinauskas

34. W. J. McCarthy, Jr.

35. J. W. Michel

36. J. P. Nichols

37. H. Postma

38. M. W. Rosenthal

39-43. T. H. Row

44. M. D. Silverman

45-47. I. Spiewak

48. J. J. Taylor

49. D. B. Trauger

50. G. D. Whitman

51. W. J. Wilcox

52. H. E. Zittel

53. ORNL Patent Office

54-55. Central Research Library

56. Document Reference Section

57-58. Laboratory Records Department

59. Laboratory Records (RC)

\section{EXTERNAL DISTRIBUTION}

60. Director, Division of Fossil Energy Research, ERDA, Washington, D.C. 20545

61. Assistant Administrator for Fossil Energy, ERDA, Washington, D.C. 20545

62. Director, Division of Coal Conversion and Utilization, ERDA, Washington, D.C. 20545

63. Mayo Carrington, Division of Coal Conversion and Utilization, ERDA, Washington, D.C. 20545

64. R. E. Vener, Division of Coal Conversion and Utilization, ERDA, Washington, D.C. 20545

65. Fred Witmer, Division of Coal Conversion and Utilization, ERDA, Washington, D.C. 20545

66. Director, Division of Nuclear Research and Applications, ERDA, Washington, D.C. 20545

67. T. Beresovski, Division of Nuclear Research and Applications, ERDA, Washington, D.C. 20545 
68. D. E. Erb, Division of Nuclear Research and Applications, ERDA, Washington, D. C. 20545

69. K. O. Laughon, Division of Nuclear Research and Applications, ERDA, Washington, D.C. 20545

70. J. C. Montgomery, Division of Nuclear Research and Applications, ERDA, Washington, D.C. 20545

71. R. G. Oeh1, Division of Nuclear Research and Applications, ERDA, Washington, D.C. 20545

72. J. H. Swisher, Division of Conservation Research and Technology, ERDA, Washington, D.C. 20545

73. A. T. McMain, General Atomic Co., P. 0. Box 81608, San Diego, Calif. 92138

74. R. N. Quade, General Atomic Co., P.0. Box 81608, San Diego, Calif. 92138

75. G. H. Farbman, Westinghouse Electric Corp., Astronulcear Laboratory P. O. Box 10864, Pittoburgh, Pa. 15236

76. A. R. Jones, Westinghouse Electric Corp., Astronuclear Laboratory P. 0. Box 10864 , P1ttsburgh, Pa. 15236

77. A. E. Kakretz, General Electric Co., Fairfield, Conn. 06431

78. 0. G. Woike, General Electric Co., P. O. Box 15132, Cincinnati, Ohio $4: 5215$

79. J. H. Crowley, United Engineers \& Constructors, 1401 Arch St., Philadelphia, Pa. 19105

80. J. B. Newman, United Engineers \& Constructors, 1401 Arch St., Philadelphia, Pa. 19105

81. D. J. Blickwede, Bethlehem Steel Corp., Bethlehem, Pa. 18016

82. T. F. Barnhart, U. S. Steel Corp., 125 Jamison Lane, Monroeville, Pa. 15146

83. H. W. Paxton, U. S. Steel Corp., 125 Jamison Lane, Monoreville, Pa. 15146

84. R. W. Wendes, Amoco Oil Co., Box 6110A, Chicago, Ill. 60680

83. D. C. Azb111, Shel1 011 Co., One She11 Plaza, P. 0. Bux 2463, Houston, Tex. 77001

86. F. M. Richmond, Universal-Cyclops, 650 Washington Rd., Pittsburgh, $\mathrm{Pa} .15228$

87. Derek Gregory, Institute of Gas Technology, 3424 South State St., Ghicago, I11. 60616

88. R. J. Jiacoletti, Los Alamos Scientific Laboratory, P. O. Box 1663, Los Alamos, N.M. 87544

89. Donald Bogart, National Aeronautics and Space Administration, 6390 Nelwood Rd., Cleveland, Ohio 44135

90. D. R. Stone, National Aeronautics and Space Administration, Washington, D.C. 20546

91. Jack G. Connors, Battelle-Columbus Laboratory, 505 King Ave., Columbus, Ohio 43201

92. F. E. Faris, Interdevelopment, Inc., Suite 1014, Rutherford B. Hayes Bldg., 2361 S. Jefferson Davis Hwy., Arlington, Va. 22202

93. Seymour Alpert, Electric Power Research Institute, 3412 Hillview Ave., Palo Alto, Calif. 94304 
93. A. Flowers, American Gas Association, 1515 Wilson Blvd., Arlington, Va. 22209

94. W. C. Helt, National Association, 1103 17th St., NW, Washington, D.C. 20036

95. W. W. Talley, Resource Analysis \& Management Group, 2500 First National Center, Oklahoma, City, Okla. 73102

96. Don Crego, Gilbert Associates, 525 Lancaster Ave., Reading, $\mathrm{Pa} .19603$

97. M. Steinburg, Brookhaven National Laboratory, Upton, N.Y. 11973

98. Engineering Technology Division, ORO, Oak Ridge, Tenn. 37830

99. Research and Technical Support Division, ORO, Oak Ridge, Tenn. 37830

100-126. Technical Information Center, Oak Ridge, Tenn. 37830

127. Dr. Lester D. Taylor, Professor of Economics, University of Arizona, Tucson, Arizona 85721

128. McCauley Whiting, The Dow Chemical Company, 2020 Dow Center, Midland, Michigan 48640

129. Hans. S. Landsberg, Company Director, Energy \& Materials Division Resources for the Future, 1755 Massachusetts Ave., NW, Washington, D.C. 20036

130. Rene H. Males, Director, Energy Analysis and Environmental Division, Electric Power Research Inst., 3412 Hillview Ave. P. O. Box 10412, Palo Alto, Calif. 94303

131-135. Car1 D. Baumann, 104 Pelham Road, Oak Ridge, Tenn. 37830 